\title{
PENERAPAN PRINSIP-PRINSIP ISLAM DALAM PENGATURAN CORPORATE SOCIAL RESPONSIBILITY DI INDONESIA
}

\author{
Artha Ully ${ }^{1}$, Abdullah Kelib ${ }^{2}$.
}

\begin{abstract}
ABSTRAK
Corporate Social Responsibility (CSR) merupakan salah satu bentuk implementasi Good Corporate Governance (GCG) sebagai tanggung jawab sosial terhadap masyarakat dan lingkungan. CSR merupakan adalah upaya untuk mencapai kesejahteraan masyarakat, tapi selama ini belum terdapat konsep alternatif CSR yang digali dari nilai-nilai yang terdapat di dalam sistem budaya dan kepercayaan termasuk ajaran Islam, padahal nilai-nilai yang dibangun oleh setiap budaya dan kepercayaan bertujuan untuk mencapai kesejahteraan masyarakat. Sebenarnya prinsip-prinsip Islam dapat bersinergi dengan baik bila disandingkan konsep CSR. Melihat perkembangan CSR yang telah diadopsi ke dalam peraturan perundang-undangan, maka dapat ditelusuri bagaimana penerapan prinsip-prinsip Islam dalam peraturan CSR di Indonesia.

Permasalahan penelitian ini adalah bagaimana konsep CSR dalam Islam dan penerapan prinsip-prinsip Islam dalam pengaturan CSR di Indonesia. Penelitian ini bertujuan untuk memahami konsep CSR dalam Islam dan penerapan prinsip-prinsip Islam tersebut ke dalam pengaturan CSR di Indonesia.

Penelitian ini merupakan penelitian hukum normatif yang mengacu pada bahan primer, sekunder dan tersier. Penelitian ini merupakan penelitian terhadap sinkronisasi hukum dan perbandingan hukum dengan menggunakan tahapan-tahapan berpikir secara sistematis untuk menjawab permasalahan.

Hasil penelitian adalah bahwa konsep CSR sebenarnya terdapat dalam ajaran Islam, Islam sejak lama telah lama membangun sistem kehidupan yang berdasarkan prinsip-prinsip sosial dan keadilan. Lima prinsip (aksioma) etika bisnis Islam dapat diadopsi menjadi konsep CSR dalam Islam, yaitu tauhid, keseimbangan atau kesejajaran, kehendak bebas, dan tanggung jawab. Sebagian dari prinsip-prinsip ini sudah diterapkan ke dalam peraturan perundang-undangan mengenai CSR di Indonesia yang terdiri dari UUD 1945, UU PT, UU PM, UU Ketenagakerjaan, UU BUMN, UU HAM, UU PLH dan peraturan lainnya, tapi masih belum diatur secara rinci.

Pemerintah sebaiknya segera merubah peraturan mengenai CSR agar tercipta sinkronisasi peraturan mengenai CSR dan membuat standar kegiatan CSR yang lebih terperinci khususnya peraturan mengenai pelaksanaan CSR pada kegiatan usaha yang berlandaskan hukum syariah agar sesuai dengan ajaran Islam. Para pihak yaitu Pemerintah, perusahaan dan masyarakat sebaiknya mempelajari CSR secara utuh yang
\end{abstract}

\footnotetext{
${ }^{1}$ Mahasiswa Program Studi Magister IImu Hukum Undip

${ }^{2}$ Dosen Program Magister Ilmu Hukum Undip
} 
disandingkan dengan prinsip-prinsip Islam untuk menjawab tantangan pencapaian keseimbangan triple bottom line.

Kata Kunci: Corporate Social Responsibility, Triple Bottom Line, Etika Bisnis Islam, Good Corporate Governance

\section{A. PENDAHULUAN}

\section{A.1. Latar Belakang}

Salah satu pilar pembangunan perekonomian Indonesia yang dapat membantu mewujudkan kesejahteraan adalah perusahaan, keberadaan perusahaan berperan untuk memajukan suatu masyarakat, daerah dan negara. Selama ini kebanyakan perusahaan dalam menjalankan usahanya hanya memikirkan keuntungan sebagai tujuan utama (profit oriented), sehingga sebuah perusahaan menggunakan berbagai macam cara untuk meraih keuntungan yang sebanyakbanyaknya tanpa memperhatikan akibat perbuatannya.

Salah satu upaya untuk mencegah berlangsungnya kegiatan bisnis yang merugikan tersebut diperlukan penerapan good corporate governance (selanjutnya disebut GCG) sebagai suatu etika bisnis, etika bisnis lahir sebagai tuntunan perilaku bagi dunia usaha untuk bisa membedakan hal yang boleh dilakukan dan hal yang tidak boleh dilakukan. Keberadaan suatu perusahaan tidak bisa dipisahkan dengan masyarakat sebagai lingkungan eksternalnya, dari aspek ekonomi, perusahaan harus berorientasi mendapatkan keuntungan dan dari aspek sosial perusahaan harus memberikan kontribusi positif secara langsung kepada masyarakat yaitu meningkatkan kualitas kehidupan masyarakat dan pelestarian lingkungan di sekitar perusahaan tersebut sebagai wujud GCG kepada stakeholders dan shareholders.

Salah satu prinsip GCG adalah responsibility, responsibility merupakan bentuk pertanggungjawaban perusahaan. Bentuk responsibility diantaranya adalah mematuhi aturan yang berlaku, memajukan masyarakat dan memelihara lingkungan di sekitar wilayah bisnis perusahaan tersebut bersama masyarakat. 
Menurut konteks ini bisnis bukan hanya semata-mata persoalan memaksimalkan keuntungan bagi pemilik perusahaan, tetapi bagaimana bisnis dijalankan secara lebih manusiawi dengan melakukan langkah-langkah terpadu bersama seluruh pihak yang berkaitan langsung maupun tidak langsung dengan keberadaan perusahaan. Karena tidak dapat dihindari kegiatan usaha pasti berdampak langsung maupun tidak langsung pada kehidupan masyarakat, sehingga perusahaan harus mendapat dukungan masyarakat.

Salah satu bentuk responsibility perusahaan adalah corporate social responsibility (selanjutnya disebut CSR), dengan demikian penerapan CSR merupakan salah satu bentuk implementasi GCG sebagai perusahaan yang bertanggung jawab terhadap masyarakat dan lingkungan.

Selama ini belum terdapat konsep alternatif CSR yang digali dari nilainilai yang terdapat di dalam sistem budaya dan kepercayaan, padahal nilai-nilai yang dibangun oleh setiap budaya dan kepercayaan bertujuan untuk mencapai kesejahteraan masyarakat.

Berbagai prinsip yang terdapat dalam ajaran Islam dapat bersinergi dengan baik bila disandingkan prinsip-prinsip CSR, karena aktivitas bisnis dilihat sebagai salah satu bentuk ibadah kepada Allah SWT. Islam adalah agama yang mengatur seluruh sendi kehidupan manusia dan alam semesta, kegiatan perekonomian manusia juga diatur dalam Islam. Islam berusaha menyeimbangkan antara nilai moral dan ekonomi, hal ini dapat dilihat dalam Surat Al Israa ayat 35: Dan sempurnakanlah takaran apabila kamu menakar dan timbanglah dengan neraca yang benar. Itulah yang lebih utama (bagimu) dan lebih baik akibatnya. Di sini terlihat konfigurasi antara nilai-nilai moral dan orientasi ekonomi dalam Islam, konsep tanggung jawab sosial telah menjadi pondasi utama dalam komunitas masyarakat muslim. Nabi Muhammad telah menanamkan nilai-nilai moral dan sosial yang terdapat dalam Al Qur'an melalui perbuatannya (sunah) dalam setiap aspek kehidupan umatnya baik itu kegiatan ekonomi maupun 
pemerintahan, sehingga kemudian dapat membentuk kesatuan komunitas yang kuat.

CSR dalam Islam tidak hanya dilakukan sebagai langkah untuk mencegah dampak negatif yang ditimbulkan oleh perusahaan, CSR dalam Islam melekat dalam seluruh kegiatan yang dilakukan perusahaan. Aktivitas perusahaan wajib dilakukan berdasarkan aturan agama Islam dan didasari dengan tauhid sebagaimana dirangkum dalam rukun iman dan rukun Islam.

Islam menganggap masalah yang berkaitan dengan perilaku etis sebagai bagian penting dari tatanan moral. Al Qur'an dan Sunah Nabi Muhammad SAW menekankan bahwa pengusaha Muslim harus berbuat baik dan bertindak sesuai dengan perintah Allah SWT.

Pernyataan di atas menunjukan bahwa Islam tidak hanya mengatur kehidupan seseorang Muslim, tetapi juga standar yang jelas tentang bagaimana suatu kegiatan usaha harus berjalan. Islam juga mengatur aspek pengambilan keputusan yang dilakukan oleh suatu perusahaan dalam setiap kegiatan bisnisnya, hal ini merupakan suatu bentuk etika bisnis termasuk konsep dasar CSR.

CSR juga merupakan komitmen perusahaan terhadap keberlanjutan sumber daya alam. Alam dapat dianggap sebagai pemangku kepentingan yang relevan, alam merupakan faktor yang mempengaruhi oleh dan memengaruhi kinerja perusahaan. Dengan daya dukung lingkungan, maka perusahaan dapat beroperasional demi pencapaian tujuan finansial. Dan sebaliknya, ketidakmampuan daya dukung lingkungan akan berpengaruh terhadap pencapaian finansial korporasi.

Perhatian atas sumber daya alam dalam Islam direpresentasikan dalam ayat-ayat Al- Quran. Salah satunya Surat Al Baqarah ayat 11 yang pada intinya menyatakan, “.... Janganlah kamu membuat kerusakan di muka Bumi....”. Aktivitas kepedulian sosial tersebut diamanahkan dalam Surat Al-Hadid ayat 18, 
"sesungguhnya orang-orang yang bersedekah, pria dan wanita, dan meminjamkan kepada Allah pinjaman yang baik, niscaya akan dilipatgandakan kepada mereka; dan bagi mereka pahala yang banyak".

Di Indonesia CSR merupakan hal yang baru, sehingga masih ada perusahaan yang enggan melaksanakan prinsip CSR dengan alasan ingin mencapai keuntungan maksimal. Dalam perundang-undangan Indonesia, kedudukan mengenai CSR ini semakin menguat terutama setelah dinyatakan dengan tegas dalam Undang-Undang No. 40 Tahun 2007 tentang Perseroan Terbatas, selanjutnya disebut dengan UU PT, ketentuan mengenai CSR ini terdapat pada Pasal 1 angka (3) dan Pasal 74 yang belum diatur UU PT yang terdahulu.

CSR juga diatur dalam Undang-Undang No. 25 Tahun 2007 Tentang Penananaman Modal, Undang-Undang No. 39 tahun 1999 Tentang Hak Asasi Manusia, Undang-Undang No. 23 tahun 1997 Tentang Pengelolaan Lingkungan Hidup, Undang-Undang No. 19 Tahun 2003 Tentang Badan Usaha Milik Negara, Keputusan Menteri Negara BUMN No. Kep-236/MBU/2003 dan Surat Edaran Menteri Negara BUMN No. SE-433/MBU/2003.

Pengaturan CSR melalui peraturan perundang-undangan mengubah kedudukan CSR yang semula hanya merupakan kewajiban moral menjadi kewajiban hukum, walaupun sudah diatur oleh undang-undang program-program CSR yang dijalankan oleh sebagian besar perusahaan hanya memiliki pengaruh jangka pendek dan terbatas. Kegiatan CSR selama ini hanya berperan sebagai alat promosi untuk mendapatkan citra perusahaan yang positif, padahal esensi dari CSR adalah perbaikan kualitas hidup masyarakat dalam jangka panjang, pembangunan berkelanjutan serta kelestarian lingkungan.

CSR dalam Islam melekat dalam seluruh kegiatan bisnis yang dilakukan oleh perusahaan mulai dari input, proses dan output, perusahaan yang memiliki tanggung jawab sosial memilih untuk menggunakan bahan baku yang tidak 
berbahaya bagi konsumen dan tidak menimbulkan kerusakan. Perusahaan dituntut untuk menggunakan cara-cara yang manusiawi, tidak menggunakan teknologi yang dapat mendorong terjadinya kerusakan lingkungan dan hasil produk yang aman dan hal-hal lain yang dilarang dalam ajaran Islam.

Melihat perkembangan CSR yang telah diadopsi ke dalam peraturan perundang-undangan, maka dapat ditelusuri lebih lanjut bagaimana prinsip-prinsip CSR yang terdapat dalam ajaran Islam diterapkan ke dalam peraturan CSR di Indonesia. Berdasarkan uraian di atas maka penulis mengangkat masalah harmonisasi CSR ke dalam tulisan ilmiah yang berbentuk tesis dengan judul: "Penerapan Prinsip-Prinsip Islam Dalam Pengaturan Corporate Social Responsibility (CSR) Di Indonesia”.

\section{A.2. Rumusan Masalah}

1. Bagaimanakah konsep corporate social responsibility (CSR) dalam perspektif hukum Islam?

2. Bagaimanakah penerapan prinsip-prinsip Islam dalam pengaturan corporate social responsibility (CSR) di Indonesia?

\section{A.3. Tujuan}

1. Untuk memahami kesesuaian konsep corporate social responsibility dengan prinsip-prinsip dalam hukum Islam.

2. Untuk memahami bagaimana penerapan prinsip-prinsip Islam dalam pengaturan corporate social responsibility (CSR) di Indonesia.

\section{A.4. Tinjauan Pustaka}

1. Tinjauan Umum Tentang Negara Hukum, Teori Stufenbau Dan Urgensi Penerapan Asas-Asas Yang Berkaitan Dengan Perundang-Undangan 
Dalam UUD 1945 Pasal 1 ayat 3, dinyatakan secara tegas bahwa Indonesia adalah negara hukum. Sehingga jelas negara Indonesia berdasarkan atas hukum (rechtsstaat), bukan berdasarkan atas kekuasaan belaka (machtsstaat).

Indonesia sebagai negara hukum dimana penyusunan sistem hukum positif Indonesia berkaitan erat dengan teori stufenbau. Teori ini adalah teori mengenai sistem hukum oleh Hans Kelsen yang menyatakan bahwa sistem hukum merupakan sistem anak tangga dengan kaidah berjenjang.

Pada intinya teori ini dimaksudkan untuk menyusun suatu hierarki norma-norma sehingga berlapis-lapis dan berjenjang-jenjang. Suatu peraturan baru dapat diakui, bila tidak bertentangan dengan peraturan-peraturan yang berlaku pada jenjang yang lebih tinggi. Hierarki perundang-undangan ini terbentuk suatu sistem hukum, dimana mengenai urutan hierarki perturan perundang-undangan diatur secara jelas dalam Undang-Undang No. 10 Tahun 2004 pada Pasal 7 ayat (1), yaitu:

a) UUD 1945;

b) Undang-Undang (UU)/Peraturan Pemerintah Pengganti Undang-Undang (Perpu);

c) Peraturan Pemerintah (PP);

d) Peraturan Presiden; dan

e) Peraturan Daerah (Perda).

Untuk memahami hukum suatu bangsa tidak hanya melihat peraturan saja, melainkan harus menggali asas-asasnya. Asas hukum bukan peraturan hukum, namun tidak ada hukum atau sistem hukum yang bisa dipahami tanpa mengetahui asas-asas hukum di dalamnya. Ada beberapa asas yang mendasari pengaturan kedudukan masing-masing peraturan perundang-undangan terdapat tiga asas (adagium) dalam tata urutan peraturan perundang-undangan, asas lex 
superiori derogat legi inferiori, asas lex specialis derogat legi generali, dan asas lex posteriori derogat legi priori.

\section{Tinjauan Umum Tentang CSR}

\section{1) Hubungan GCG Dengan CSR}

Secara umum istilah clean dan good governance memiliki pengertian akan segala hal terkait dengan tindakan atau tingkah laku yang bersifat mengarahkan, mengendalikan, atau mempengaruhi urusan publik untuk mewujudkan nilai tersebut dalam kehidupan sehari-hari. Sedangkan UNDP memberikan karakteristik atau prinsip good governance terdiri dari partcipation, rule of law, responsiveness, consensus orientation, effectiveness and efficiency, accountability dan strategic vision.

Berdasarkan uraian di atas UNDP memberikan definisi good governance sebagai hubungan yang sinergis dan konstruktif diantara negara, sektor swasta, dan masyarakat. Perusahaan memiliki peran sebagai sumber pendapatan atau penyandang dana serta ikut memberikan dampak positif pada masyarakat, selain berorientasi pada keuntungan. GCG memiliki lima prinsip yang dapat dijadikan pedoman bagi para pelaku bisnis, adalah sebagai berikut:

a) Transparency (keterbukaan informasi)

Secara sederhana bisa diartikan sebagai keterbukaan informasi. Dalam mewujudkan prinsip ini, perusahaan dituntut untuk menyediakan informasi yang cukup, akurat, tepat waktu kepada segenap stakeholders.

b) Accountability (akuntabilitas) 
Yang dimaksud dengan akuntabilitas adalah kejelasan fungsi, struktur, sistem dan pertanggungjawaban elemen perusahaan.

c) Responsibility (pertanggungjawaban)

Bentuk pertanggungjawaban perusahaan adalah kepatuhan perusahaan terhadap peraturan yang berlaku, diantaranya; masalah pajak, hubungan industrial, kesehatan dan keselamatan kerja, perlindungan lingkungan hidup, memelihara lingkungan bisnis yang kondusif bersama masyarakat dan sebagainya.

d) Independency (kemandirian)

Intinya, prinsip ini mensyaratkan agar perusahaan dikelola secara profesional tanpa ada benturan kepentingan dan tanpa tekanan atau intervensi dari pihak manapun yang tidak sesuai dengan peraturan-peraturan yang berlaku.

e) Fairness (kesetaraan dan kewajaran)

Prinsip ini menuntut adanya perlakuan yang adil dalam memenuhi hak stakeholders sesuai dengan peraturan perundangan yang berlaku.

Salah satu hal penting yang tidak boleh dilupakan dalam penerapan GCG adalah tanggung jawab sosial perusahaan dan etika bisnis. Sebab bisnis tidak dapat berjalan dengan baik bila dijalankan dengan cara-cara yang curang dan penipuan baik dilingkungan internal sendiri maupun eksternal perusahaan. Perusahaan tidak hanya berorientasi pada keuntungan, tetapi perlu memperhatikan prinsip GCG. Keberadaan suatu perusahaan tidak bisa dipisahkan dengan masyarakat, perusahaan harus memberikan kontribusi positif secara langsung kepada masyarakat. Perusahaan berkewajiban meningkatkan kualitas kehidupan masyarakat dan pelestarian lingkungan disekitar perusahaan tersebut sebagai bentuk responsibility perusahaan. CSR merupakan salah satu bentuk implementasi GCG sebagai perusahaan yang bertanggung jawab terhadap masyarakat dan lingkungan, perusahaan yang melaksanakan GCG harus juga melaksanakan CSR. 


\section{2) Corporate social responsibility (CSR) atau tanggung jawab sosial perusahaan}

CSR pertama kali muncul dalam diskursus resmi akademik sejak Howard R Bowen menerbitkan bukunya berjudul Social Responsibility of the Businessman pada tahun 1953. Ide dasar CSR yang dikemukakan Bowen mengacu pada kewajiban pelaku bisnis untuk menjalankan usahanya sejalan dengan nilainilai dan tujuan yang hendak dicapai masyarakat di tempat perusahaannya beroperasi. Terobosan besar dalam konteks CSR, dilakukan John Elkington pada tahun 1997 dalam bukunya Cannibals with Forks, the Tripple Bottom Line of Twentieth Century Bussiness. Elkington mengembangkan konsep triple bottom line dalam istilah economic prosperity, environmental quality, dan social justice. Melalui buku tersebut Elkington memberi pandangan bahwa perusahaan yang berkelanjutan, harus memperhatikan 3P. Hubungan antara profit, people dan planet ini dapat diilustrasikan dengan gambar sebagai berikut (gambar 1):

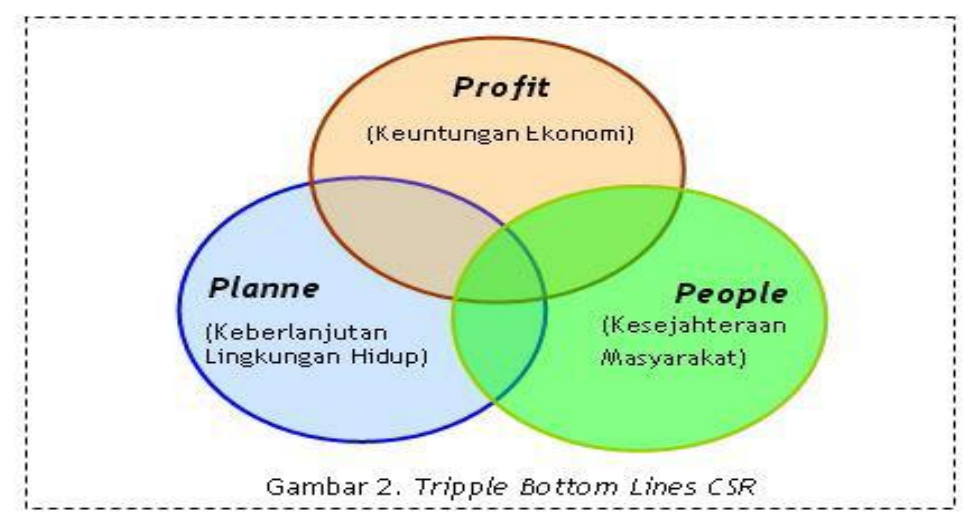

Konsep yang dicetuskan oleh Elkington pada intinya mengemukakan bahwa perusahaan yang ingin terus menjalankan usahanya harus memperhatikan 3P yaitu profit, people dan plannet. Perusahaan yang menjalankan usahanya tidak dibenarkan hanya mengejar keuntungan semata (profit), tetapi mereka juga harus terlibat pada pemenuhan kesejahteraan masyarakat (people), dan berpartisipasi 
aktif dalam menjaga kelestarian lingkungan (planet). Ketiga prinsip tersebut saling mendukung dalam pelaksanaan program CSR.

Secara global CSR mengalami kemajuan yang signifikan baik secara teori maupun prakteknya di berbagai Negara, termasuk mengenai pengertian CSR itu sendiri. Berikut ini adalah beberapa definisi CSR, yaitu:

1) International Finance Corporation memberikan definisi CSR:

Komitmen dunia bisnis untuk member kontribusi terhadap pembangunan ekonomi berkelanjutan melalui kerjasama dengan karyawan, keluarga mereka, komunitas local dan masyarakat luas untuk meningkatkan kehidupan mereka melalui caracara yang baik bagi bisnis maupun pembangunan."

2) World Bisnis Council for Sustainable Development (WBCD) menyatakan pendapatnya tentang CSR:

Suatu komitmen berkelanjutan oleh dunia usaha untuk bertindak etis dan memberikan kontribusi kepada pengembangan ekonomi dari komunitas setempat ataupun masyarakat luas, bersamaan dengan peningkatan taraf hidup pekerjanya beserta seluruh keluarga.

3) CSR Forum juga memberikan definisinya tentang CSR:

CSR means open and transparent bussiness practices that are based on ethical values and respect for employess, communities and enviroment.

4) Sedangkan konsep CSR menurut Uni Eropa (EU Green Paper On CSR):

CSR is a concept whereby companies integrate social and environmental concern in their bussiness operation and in their interaction with their stakeholders on voluntary basic.

5) World Bank mengartikan CSR sebagai suatu komitmen: 
CSR is the commitmen of bussiness to contribute to sustainable economic development working with employess and their represantives, the local community and society at large to improve quality of live, in ways that are both good for bussiness and good for development."

ISO (International Organization for Standardization) telah menyusun konsep standar CSR yang ditetapkan pada tahun 2010, yang dikenal dengan nama ISO 26000 Guidance on Social Responsibility. CSR adalah tanggung jawab sebuah organisasi terhadap dampak-dampak dari keputusan-keputusan dan kegiatan-kegiatannya pada masyarakat dan lingkungan yang diwujudkan dalam bentuk perilaku transparan dan etis yang sejalan dengan pembangunan berkelanjutan dan kesejahteraan masyarakat, mempertimbangkan harapan pemangku kepentingan, sejalan dengan hukum yang ditetapkan dan norma-norma perilaku internasional serta terintegrasi dengan organisasi secara menyeluruh.

Dalam aplikasinya, konsep 3P ini bisa dipadukan dengan komponen dalam ISO 26000. Konsep 3P terdiri dari profit (keuntungan), planet (lingkungan) dan people (manusia) yang dikenal dengan istilah triple bottom line. Keuntungan, selain mendapat keutungan tetapi harus juga mencakup konsep tata kelola perusahaan yang baik dan praktek bisnis yang etis. Planet atau lingkungan, jelas berkaitan dengan pemeliharaan dan pelestarian lingkungan. Konsep masyarakat bisa merujuk pada konsep pembangunan masyarakat yang tidak hanya menyangkut kesejahteraan ekonomi masyarakat (seperti pemberian modal usaha dan pelatihan keterampilan kerja). Tetapi juga, kesejahteraan sosial (contohnya, pemberian jaminan sosial, penguatan akses masyarakat terhadap pelayanan kesehatan dan pendididikan).

\section{c. Corporate Social Responsibility (CSR) Sebagai Bentuk Perubahan Paradigma Bisnis}

Teori yang dapat menjadi melatarbelakangi lahirnya CSR sebagai salah satu bentuk etika bisnis adalah teori utilitas (utilitarisme) yang dipelopori Jeremy 
Bentham dan selanjutnya dikembangkan oleh John Stuart Mill. Bentham menjelaskan lebih jauh bahwa asas manfaat melandasi segala kegiatan berdasarkan sejauh mana tindakan itu meningkatkan atau mengurangi kebahagiaan kelompok itu; atau, dengan kata lain meningkatkan atau melawan kebahagiaan itu. Menurut teori ini kualitas etis suatu perbuatan diperoleh dengan dicapainya tujuan perbuatan. Perbuatan yang memang bermaksud baik, tetapi tidak menghasilkan apa-apa menurut utilitarisme tidak pantas disebut baik.

Teori utilitas merupakan pengambilan keputusan etika dengan mempertimbangkan manfaat terbesar bagi banyak pihak sebagai hasil akhirnya (The greatest good for the greatest number) artinya bahwa hal yang benar didasarkan pada ukuran semakin bermanfaat pada banyak orang perbuatan itu semakin etis.

Berkaitan dengan teori yang telah dipaparkan sebelumnya, korporasi atau perusahaan dinilai telah meraih banyak manfaat dengan menguras kekayaan alam melalui teknologi dan industri. Menurut utilitarisme upaya pembangunan berkelanjutan (suistanable development) menjadi tanggung jawab moral individu atau perusahaan.

Beberapa teori mengenai korporasi telah dikembangkan selama ini, di antaranya yang paling terkenal adalah equity theory. Teori ini merupakan induk teori dari teori korporasi yang berkembang dari waktu ke waktu, teori ini pada intinya menjelaskan tentang model hubungan antara perusahaan. Konsep-konsep tentang hak kepemilikan (equalities) terus tumbuh dan berubah seiring laju pertumbuhan industri barang dan jasa serta perkembangan aspek-aspek sosial budaya yang semakin kompleks hingga melahirkan turunan teori-teori kepemilikan yang ada saat ini. Salah satu turunan teori ini adalah entity theory dan agency theory.

Entity theory mengasumsikan terjadinya pemisahan antara kepentingan pribadi pemilik ekuitas (owners) dengan entitas bisnisnya (perusahaan). 
Pendekatan ini kemudian yang paling banyak dirujuk oleh praktik-praktik bisnis secara umum. Agency theory merupakan teori yang menjelaskan tentang hubungan kontraktual antara pihak yang mendelegasikan pengambilan keputusan tertentu (pemilik/pemegang saham) dengan pihak yang menerima pendelegasian tersebut (agen/direksi/manajemen). Selain teori-teori yang telah diuraikan sebelumnya terdapat lima teori yang mendukung keberadaan CSR, yaitu:

a) Corporate Accountability Theory

Perusahaan harus bertanggungjawab atas semua konsekuensi yang ditimbulkannya baik sengaja maupun tidak sengaja kepada para pemangku kepentingan (stakeholders).

\section{b) Stakeholders Theory}

Teori ini menyatakan bahwa kesuksesan suatu perusahaan sangat tergantung dengan kemampuannya menyeimbangkan beragam kepentingan daripada stakeholders.

c) Legitimacy Theory

Teori kontrak sosial menyatakan bahwa keberadaan perusahaan dalam suatu area karena didukung secara politis dan dijamin oleh regulasi pemerintah serta parlemen yang juga merupakan representasi dari masyarakat.

d) Corporate Sustainable Theory

Menurut teori ini agar bisa hidup dan tumbuh secara berkelanjutan, korporasi harus mengintegerasikan tujuan bisnis dengan tujuan sosial dan ekologi secara utuh.

e) Political and Economic Theory

Menurut teori ini, domain ekonomi tidak dapat diisolasikan dari lingkungan dimana transaksi ekonomi dilakukan. 


\section{f) Justice Theory}

Menurut teori ini, dalam sistem kapitalis pasar bebas laba/rugi sangat tergantung pada the unequal rewards and privilege yang terdapat dalam laba dan kompensasi. Laba/rugi mencerminkan ketidakadilan para pihak yang dinikmati atau diderita suatu perusahaan. Karena itu, perusahaan harus adil terhadap masyarakat dan lingkungan sekitarnya.

\section{Tinjauan Umum Tentang CSR Dalam Islam}

\section{1) Sumber-Sumber Hukum Islam}

\section{a. Al Qur'an}

Al Qur'an memiliki banyak peranan untuk manusia seperti sumber panduan hidup, penjelas tujuan hidup, mengisi jiwa yang kosong dan termasuklah menerangkan apa yang memberi maslahat serta mengelak mudarat bagi manusia yang terakhir inilah disebut sebagai hukum. Ayat hukum ini terdiri dari hukum ibadah, hukum siyasah atau politik, hukum jenayah atau pidana, hukum keluarga dan hukum ekonomi.

\section{b. Hadist/Sunah}

Sumber hukum Islam yang kedua adalah sunah yaitu sesuatu yang datang dari Nabi SAW baik berupa perkataan atau perbuatan dan atau persetujuan Dasar hukum Sunah atau hadis menjadi sumber hukum Islam adalah Al Qur'an, Allah menyatakan bahwa Rasulullah wajib memutuskan persoalan-persoalan yang dihadapi umat Muslim dengan dasar wahyu. Secara singkat hadist dapat diartikan sebagai setiap hal yang berasal dari Nabi Muhammad, baik berupa perbuatan, perkataan atau persetujuan Nabi.

\section{c. Ijma'}

Pengertian Ijma' secara etimologis memiliki dua arti yaitu berupaya (tekad) terhadap sesuatu atau kesepakatan. Perbedaan arti yang pertama dengan 
yang kedua ini bahwa arti pertama berlaku untuk satu orang dan arti kedua lebih dari satu orang. Ijma' dalam istilah ahli ushul adalah kesepakatan semua para mujtahid dari kaum muslimin dalam suatu waktu setelah wafatnya Nabi Muhammad atas hukum syara.

\section{d. Qiyas}

Secara etimologis, qiyas berarti mengukur, memastikan, dan membandingkan sesuatu. Sementara itu, secara istilah ushul fiqh, qiyas adalah menghubungkan suatu perkara yang tidak ada nash tentang hukumnya kepada perkara lain yang ada nash hukumnya karena adanya persamaan illat (hukum). Dengan demikian qiyas itu penerapan hukum analogi terhadap hukum sesuatu yang serupa karena prinsip persamaan illat akan melahirkan hukum yang sama pula.

\section{2) Prinsip-Prinsip Hukum Ekonomi Islam Berkaitan Dengan CSR}

Islam mempunyai prinsip pertanggungjawaban yang seimbang dalam segala bentuk dan ruang lingkupnya. Antara jiwa dan raga, antara individu dan keluarga, antara individu dan sosial dan, antara suatu masyarakat dengan masyarakat yang lain. Tanggung jawab sosial merujuk pada kewajibankewajiban sebuah perusahaan untuk melindungi dan memberi kontribusi kepada masyarakat dimana perusahaan itu berada. Sebuah perusahaan mengemban tanggung jawab sosial dalam tiga aspek:

a) pelaku-pelaku organisasi, meliputi:

(a) hubungan perusahaan dengan pekerja (QS. An Nisa ayat 149);

(b) hubungan pekerja dengan perusahaan;

(c) hubungan perusahaan dan pelaku usaha lain seperti, distributor, konsumen dan pesaing;

b) lingkungan alam (QS. Al A'raf ayat 56); dan 
c) kesejahteraan sosial masyarakat.

Selain itu juga terdapat prinsip Islam yang diterapkan dalam menjalankan bisnis yang berkaitan dengan CSR, yaitu:

a) menjaga lingkungan dan melestarikannya (Surat Al Maidah ayat 32);

b) upaya untuk menghapus kemiskinan (Surat Al Hasyr ayat 7);

c) mendahulukan sesuatu yang bermoral bersih daripada sesuatu yang secara moral kotor, walaupun mendatangkan keuntungan yang lebih besar (Surat Al Maidah ayat 103); dan

d) jujur dan amanah (Surat Al Anfal ayat 27).

\section{A.5. Metode Penelitian}

\section{Pendekatan Masalah}

Penelitian ini adalah penelitian hukum normatif yaitu penelitian yang dilakukan dengan mengumpulkan bahan hukum baik primer, sekunder maupun tersier. Penelitian ini menggunakan metode pendekatan undang-undang (statute approach), yaitu dilakukan dengan menelaah undang-undang dan regulasi yang berkaitan dengan isu hukum yang sedang dikaji.

Berdasarkan rumusan masalah yang ada, maka penelitian ini juga merupakan penelitian terhadap sinkronisasi hukum. Penelitian ini merupakan penelitian hukum normatif dengan metode pendekatan perbandingan hukum (comparative approach), dalam pengertian yang paling sederhana, merupakan suatu metode studi dan penelitian dimana hukum-hukum dan lembaga-lembaga hukum dari dua negara atau lebih diperbandingkan dalam rangka menemukan solusi guna menjawab berbagai masalah hukum.

\section{Spesifikasi Penelitian}


Spesifikasi penelitian ini termasuk dalam kategori penelitian hukum yang bersifat spesifikasi deskriptif analitis, yaitu suatu penelitian yang berusaha menggambarkan masalah hukum, sistem hukum, dan mengkajinya atau menganalisanya sesuai dengan kebutuhan dari penelitian tersebut.

\section{Jenis Data}

Dalam penelitian ini digunakan bahan-bahan hukum berupa peraturan perundangan, penelitian didasarkan pada aturan perundangan sebagai bahan hukum utama penelitian. Isu hukum dalam penelitian normatif adalah hal penting yang dipecah menjadi pertanyaan penelitian demikian juga penelitian bahan hukum yang terdiri dari bahan hukum primer, sekunder dan tersier. Di dalam penelitian hukum normatif, digunakan data sekunder yang mencakup:

a. Bahan hukum primer, yaitu bahan-bahan hukum yang mengikat dan terdiri dari:

a) Norma dasar atau kaidah dasar, yaitu Pancasila;

b) Peraturan dasar, mencakup diantaranya Batang Tubuh UUD 1945 yaitu Pasal 33 ayat 1 dan 4 .

c) Peraturan Perundang-undangan, yang terdiri dari:

1) Undang-Undang No. 40 Tahun 2007;

2) Undang-Undang No. 19 Tahun 2003;

3) Undang-Undang No. 25 Tahun 2007;

4) Undang-Undang No. 39 tahun 1999 Tentang Hak Asasi Manusia;

5) Undang-Undang No. 23 tahun 1997 Tentang Pengelolaan Lingkungan Hidup;

6) Keputusan Menteri Negara BUMN No. Kep-236/MBU/2003; 
7) Surat Edaran Menteri Negara BUMN No. SE-433/MBU/2003;

8) Peraturan Menteri Negara BUMN No. Per-05/MBU/2007.

b. Bahan hukum sekunder, yang memberikan penjelasan mengenai bahan hukum primer, seperti rancangan peraturan perundang-undangan, hasilhasil penelitian seperti jurnal dan makalah.

c. Bahan hukum tersier, yakni bahan yang memberikan petunjuk maupun penjelasan terhadap bahan hukum primer dan sekunder; contohnya adalah kamus, ensiklopedia, dan sebagainya.

\section{Metode Pengumpulan Data}

\section{a. Studi dokumentasi.}

\section{b. Penelusuran literatur hukum}

\section{Metode Analisis Data}

Penelitian hukum normatif merupakan penelitian hukum yang hanya mengenal data sekunder, yaitu meliputi bahan hukum primer, sekunder, dan tersier. Penelitian normatif tentu harus menggunakan pendekatan perundangundangan, karena yang akan diteliti adalah berbagai aturan hukum yang menjadi fokus sekaligus tema sentral suatu penelitian.

Selain itu penelitian ini menggunakan pendekatan perbandingan (comparative approach) sebagai alat bantu agar analisis hukum yang dihasilkan lebih akurat, metode perbandingan hukum diterapkan dengan memakai unsurunsur sistem hukum sebagai titik tolak perbandingan.

Perbandingan dapat dilakukan terhadap masing-masing unsure atau secara komulatif terhadap semuanya, perbandingan dapat dilakukan terhadap berbagai sub sistem hukum yang berlaku di masyarakat tertentu atau secara lintas sektoral terhadap sistem-sistem hukum di berbagai masyarakat berbeda. 


\section{B. Hasil Penelitian Dan Pembahasan}

\section{B.1. Konsep CSR Dalam Islam}

\section{Etika Bisnis Dalam Islam}

Etika bisnis Islam dilatarbelakangi oleh ajaran Islam itu sendiri, bermula dari tujuan Nabi Muhammad SAW diutus oleh Allah SWT untuk menyempurnakan akhlak atau etika. Landasan normatif dalam etika bisnis Islam sudah pasti bersumber dari ajaran Islam, yaitu Al Qur'an yang telah banyak memberikan acuan bagi para pelaku bisnis dalam menjalankan atau mengelola bisnis secara Islami.

Nilai-nilai ajaran Islam berdasarkan yaitu hukum Islam yang mengacu pada Al Qur'an, hadis (sunah nabi, yaitu perbuatan atau perkataan yang dilakukan oleh nabi Muhammad) ijma (kesepakatan para ulama) dan qiyas (analogi). Ajaran Islam yang diturunkan oleh Allah bertujuan untuk memberikan kebaikan kepada manusia atau menjauhkan mereka daripada keburukan, ini sejalan dengan tujuan sistem sosial dalam Islam yang berdasarkan pada falah (kesejahteraan) dan hayat tayyibah (kehidupan yang baik).

Kegiatan bisnis menurut Islam adalah serangkaian aktivitas bisnis dalam berbagai bentuknya yang tidak dibatasi jumlah kepemilikan barang atau termasuk profitnya, namun dibatasi mengenai cara memperolehnya dan pendayagunaan harta tersebut karena terikat pada aturan halal dan haram. Halal dan haram adalah persoalan penting dalam ajaran Islam, pedoman untuk setiap Muslim dalam setiap aktivitasnya.

Tabel 2: Prinsip-Prinsip Dasar Dalam Transaksi Bisnis Islam (Kegiatan Bisnis Yang Dianjurkan Dan Dilarang)

\begin{tabular}{|l|l|}
\hline Transaksi Bisnis Yang Halal & Transaksi Bisnis Yang Haram \\
\hline Penghasilan Yang Halal & Bunga/Riba \\
\hline
\end{tabular}




\begin{tabular}{|l|l|}
\hline $\begin{array}{l}\text { Perlakuan Yang Adil Pada Pekerjal } \\
\text { (Asas Nondiskriminatif) }\end{array}$ & Penapan Harga \\
\hline Kedermawanan Dan Toleransi & Najasy \\
\hline Kepercayaan & Kecurangan Dan Penipuan \\
\hline Kebenaran Dan Kejujuran & Menjual Barang Telarang \\
\hline Kesepatan & $\begin{array}{l}\text { Kenarar (Perdagangan dengan Unsur } \\
\text { Pemenuhan Kewajiban/Menepastian, resiko dan spekulasi } \\
\text { Janji }\end{array}$ \\
\hline
\end{tabular}

1) Transaksi Bisnis Yang Dianjurkan (Halal) Dalam Islam

\section{a. Penghasilan Yang Halal}

Islam memandang kehalalan suatu benda sangat penting dalam kehidupan umat manusia, termasuk penghasilan seorang Muslim. Allah SWT memerintahkan agar umat manusia selalu mencari sesuatu yang halal dan menjauhi sesuatu yang haram, sebagaimana firman Allah SWT dalam Surat Al Baqarah Ayat 168, "Wahai manusia! Makanlah yang halal dan baik dari makanan yang ada di bumi, dan janganlah kamu mengikuti langkah-langkah setan, sungguh setan itu musuh yang nyata bagimu."

Halal yang dimaksud pada ayat di atas adalah halal dalam memperoleh sesuatu termasuk penghasilan dan halal dalam mengkonsumsi atau memanfaatkan. Halal dalam memperoleh sesuatu adalah cara memperoleh barang atau rezeki dengan jalan yang halal, cara yang halal merupakan jalan yang wajib dilakukan seorang Muslim untuk mendapatkan penghasilan. Hal tersebut berarti bahwa seorang muslim harus memiliki etos kerja yang tinggi dalam mencari rezeki dengan tetap memperhatikan ketentuan Allah SWT yang berkaitan dengan kehalalan harta. Halal dalam memanfaatkan adalah bagaimana harta yang telah dihasilkan dengan cara halal dimanfaatkan juga untuk mengkonsumsi benda-benda yang diperbolehkan (halal), seorang Muslim harus menempatkan kecintaannya pada harta pada tempat yang semestinya. 


\section{b. Kebenaran Dan kejujuran}

Secara istilah jujur adalah lurus hati atau tidak curang, yang artinya seseorang yang mengamalkan nilai jujur adalah seseorang yang hatinya tidak mudah dibelokan oleh sesuatu yang sifatnya tidak benar. Jujur berarti tidak curang karena bersikap sesuai dengan ukuran benar dan salah, baik menurut dirinya ataupun menurut ukuran nilai-nilai yang berlaku. Kejujuran dalam ajaran Islam disebut dengan istilah shiddiq yang berarti mempunyai kejujuran dan selalu melandasi ucapan, keyakinan dan amal perbuatan atas dasar nilai-nilai kebenaran yang diajarkan Islam. Dalam bisnis Islam, kunci utama yang harus dikedepankan adalah kejujuran. Kejujuran ditunjukan dengan setiap perkataan yang dibuktikan dengan perilaku, berpijak pada kebenaran dan sesuai fakta yang ada.

Jujur adalah sifat penting bagi Islam, sifat jujur dan amanah adalah serangkaian sifat Nabi Muhammad yang perlu diteladani oleh seorang Muslim. Nabi Muhammad adalah seseorang yang mempunyai sifat jujur dan terpercaya, oleh sebab itu kita patut menjadikan Nabi Muhammad sebagai suri teladan yang baik sebagaimana disampaikan pada Allah SWT dalam firmanNya berikut ini:

Sesungguhnya telah ada pada (diri) Rasulullah itu suri teladan yang baik bagimu (yaitu) bagi orang yang mengharap (rahmat) Allah dan (kedatangan) hari kiamat dan dia banyak menyebut Allah. (QS. Al Ahzab Ayat 21)

Kejujuran dalam kegiatan bisnis merupakan keharusan, menurut ajaran Islam derajat kesempurnaan manusia tertinggi. Setiap Muslim harus selalu berkata benar dalam bebagai keadaan termasuk dalam kegiatan bisnis. Sifat jujur merupakan bukti keimanan, dasar agama seorang Muslim. Bersikap jujur sangat dianjurkan dalam Islam, kejujuran senantiasa 
mendatangkan berkah dalam setiap aktivitas yang dilakukan oleh seorang Muslim.

\section{c. Kepercayaan Sebagai Etika Bisnis Islam}

Kepercayaan adalah sifat dasar dalam Islam yang dapat ditemukan pada dua kalimat syahadat, yaitu "laa ilaha illallah muhammadur rasulullah" yang berarti "tiada tuhan selain Allah, Muhammad adalah utusan Allah". Kepercayaan merupakan pondasi dalam ajaran Islam, Islam disebarkan dengan modal kepercayaan yang dibawa oleh Nabi Muhammad SAW yang bergelar Al Amin. Kepercayaan (amanah) merupakan prinsip yang penting dan berhubungan erat dengan keimanan, hal ini disebutkan dalam firman Allah berikut ini: Hai orang-orang yang beriman, janganlah kamu mengkhianati Allah dan Rasul (Muhammad) dan (juga) janganlah kamu mengkhianati amanat-amanat yang dipercayakan kepadamu, sedang kamu mengetahui. (QS. An Anfal Ayat 27).

Firman Allah di atas meletakan kepercayaan sebagai hal yang harus diutamakan oleh seorang Muslim, kepercayaan juga mempunyai dimensi yang sangat luas sekali. Kepercayaan memiliki peran menumbuhkan dan mengembangkan bisnis, apabila kepercayaan menentukan keberlangsungan suatu kegiatan bisnis tersebut. Kepercayaan harus dibuktikan dengan perbuatan, sehingga kepercayaan bukan hal yang dapat diraih dengan sendirinya.

\section{d. Kesepakatan}

Perjanjian dalam Islam dikenal dengan istilah akad atau kontrak yang berasal dari bahasa Arab yang berarti ikatan atau simpulan baik ikatan yang nampak (hissyy) maupun tidak nampak (ma'nawy). Akad juga dapat didefinisikan sebagai suatu perbuatan yang sengaja dibuat oleh dua orang berdasarkan kesepakatan atau kerelaan bersama. 
Hukum Islam tidak membedakan antara istilah kontrak dengan perjanjian, keduanya identik dan disebut akad. berdasarkan beberapa pengertian di atas dapat diambil kesimpulan bahwa kesepakatan adalah hal yang penting dalam perjanjian $(a k a d)$, setiap perjanjian harus dibuat berdasarkan kesepakatan. Kesepakatan adalah syarat mutlak terjadinya suatu akad, hal ini disebutkan dalam Surat An Nisa Ayat 29: Hai orangorang yang beriman, janganlah kamu saling memakan harta sesamamu dengan jalan yang batil, kecuali dengan jalan perniagaan yang berlaku dengan suka sama suka di antara kamu.

Berdasarkan kandungan ayat di atas dapat dipahami bahwa segala transaksi yang dilakukan harus atas dasar kesepakatan atau kerelaan antara masing-masing pihak, tidak diperbolehkan adanya tekanan, paksaan dan penipuan dalam proses terjadinya akad. Jika hal ini tidak dipenuhi, maka transaksi tersebut dilakukan dengan cara yang batil.

\section{e. Menepati Janji (Memenuhi Akad)}

Ajaran Islam menyatakan bahwa janji itu adalah sesuatu yang harus dilaksanakan dan dihari akhir nanti diminta pertanggung jawabannya oleh Allah SWT, sebagaimana disebutkan di dalam Surah Al Israa Ayat 34: “dan penuhilah janji, sesungguhnya janji itu pasti diminta pertanggungan jawabnya.

Allah membenci orang-orang yang tidak menepati janjinya, hal ini dinyatakanNya dalam Al Qur'an, "Hai orang-orang yang beriman, mengapa kamu mengatakan apa yang tidak kamu perbuat; Amat besar kebencian di sisi Allah bahwa kamu mengatakan apa-apa yang tiada kamu kerjakan" (QS 61:2-3). 
Menepati janji merupakan jantung moral dan perilaku Islam. Sifat itu juga salah satu dari tanda-tanda yang paling mengindikasikan kebenaran keimanan serta Islam.

\section{f. Berbuat Adil Terhadap Pekerja}

Bekerja merupakan suatu kewajiban sebagaimana firmanNya dalam Surat At Taubah Ayat 105: Dan katakanlah, bekerjalah kamu, karena Allah dan Rasul-Nya serta orang-orang yang beriman akan melihat pekerjaan itu. Islam mengharuskan setiap Muslim wajib untuk bekerja termasuk menyediakan gaji yang adil untuk setiap pekerja. Islam juga menekankan agar setiap Muslim memperhatikan pekerja yang berada di bawah tanggung jawabnya dengan bersikap adil sebagai seorang pemimpin. Ajaran Islam menghargai aspek kemanusiaan, Islam telah memberi ketentuan mengenai pekerja hak-hak pekerja seperti upah yang adil dan tidak terlalu membebani pekerja untuk dipaksa bekerja melebihi kemampuannya

\section{g. Kedermawanan Dalam Islam}

Dorongan utama seorang Muslim untuk bekerja adalah untuk mendapatkan penghasilan, penghasilan dapat diartikan juga sebagai harta. Bekerja merupakan bagian dari ibadah, maka bekerja harus dilakukan dengan prinsip kehati-hatian sehingga terlepas dari perihal perbuatan yang dapat merugikan orang lain dan hal-hal yang dilarang oleh Islam. Al Qur'an sebagai pedoman hidup manusia menyebutkan bahwa inti kepemilikan segala harta yang ada di bumi ini merupakan milik Allah SWT yang dianugerahkan untuk kehidupan manusia sebagai khalifah.

Pengelolaan harta yang dimiliki seorang Muslim harus sesuai dengan prosedur yang telah ditentukan oleh Allah, termasuk mengenai masalah zakat. Zakat adalah bukti kedermawanan seorang Muslim dan merupakan kewajiban yang harus dilaksanakan, karena harta yang seorang Muslim 
tidak utuh menjadi hak miliknya. Harta yang didapat oleh seorang Muslim melalui bekerja adalah ibadah, sehingga harta yang dihasilkan harus dimanfaatkan untuk memenuhi kebutuhan hidup dan membantu orang lain secara seimbang. Kedermawanan seorang Muslim harus berdimensi sosial terhadap masyarakat, karena orang yang membutuhkan juga memiliki hak di dalam sebagian harta seorang Muslim.

\section{2) Kegiatan Bisnis Yang Dilarang Dalam Islam}

\section{a. Larangan Terhadap Kecurangan dan Penipuan}

Al Qur'an melarang kecurangan dan penipuan dalam bentuk apapun, sifat ini digambarkan oleh Al Qur'an sebagai karakter utama kemunafikan. Islam sangat melarang penipuan dan kecurangan dalam kegiatan bisnis karena dapat menyebabkan kerugian, permusuhan dan konflik.

Transaksi bisnis yang dilakukan dengan kecurangan dilarang dalam

Islam, oleh karena itu seorang Muslim harus bersikap jujur di dalam setiap perbuatannya. Kecurangan merupakan sebab timbulnya ketidakadilan, padahal keadilan adalah salah satu nilai moral ajaran Islam yang utama.

Penghargaan ajaran Islam terhadap kegiatan bisnis berangkat dari ketentuan Allah bahwa setiap aktivitas bisnis yang dilakukan seorang Muslim harus dilaksanakan secara baik atas dasar kerelaan. Berdasarkan uraian sebelumnya dapat diambil kesimpulan bahwa Islam menekankan pentingnya kejujuran dalam menakar dan menimbang pada setiap kegiatan bisnis yang dilakukan seorang Muslim.

\section{b. Larangan Terhadap Rekayasa Harga}

Islam pada prinsipnya tidak melarang setiap kegiatan bisnis yang dilakukan seorang Muslim, kecuali ada unsur-unsur kezaliman, penipuan, 
penindasan dan mengarah kepada sesuatu yang dilarang. Konsep Islam menegaskan bahwa kegiatan bisnis harus berdiri di atas prinsip persaingan bebas, namun demikian bukan berarti kebebasan tersebut harus sesuai dengan ajaran Islam.

Penetapan harga atau rekayasa harga oleh salah satu pihak untuk mendapatkan keuntungan dilarang dalam Islam, karena penetapan harga harus berdasarkan kesepakatan kedua belah pihak. Penetapan harga baru diperbolehkan bahkan diwajibkan bila bertujuan untuk keadilan, seperti menetapkan undang-undang untuk tidak menjual di atas harga resmi oleh pemerintah.

\section{c. Larangan Terhadap Praktek Riba}

Islam dalam memperkeras persoalan haramnya riba, semata-mata demi melindungi kemaslahatan manusia, baik dari segi akhlaknya, masyarakatnya maupun perekonomiannya. Larangan mengenai riba terdapat di dalam Al Qur'an, yaitu Surat Al Imran Ayat 130:

"Hai orang-orang yang beriman, janganlah kamu memakan riba dengan berlipat ganda dan bertakwalah kamu kepada Allah supaya kaти mendapat keberuntungan."

Syariat Islam memandang riba adalah salah satu dosa yang sangat besar dan berbahaya, praktek riba ini sangat merugikan masyarakat. Berikut ini beberapa dampak negatif riba bagi masyarakat, yaitu:
a). Bagi jiwa manusia
b). Bagi masyarakat
c). Bagi pergerakan ekonomi

\section{d. Larangan Terhadap Penimbunan Komoditas (Ihtikar)}


Ihtikar artinya menimbun barang agar yang beredar di masyarakat berkurang, ketika harga barang tersebut naik yang menimbun memperoleh keuntungan besar dan masyarakat dirugikan. Tujuan Ihtikar adalah menaikkan harga barang kebutuhan masyarakat dengan cara memborong kebutuhan pokok dan menimbunnya terlebih dahulu kemudian menjual barang tersebut pada saat harganya mengalami kenaikan.

Sebab ihtikar dilarang adalah mencegah hal-hal yang menyulitkan manusia secara umum, baik itu kebutuhan pokok atau bukan. Ihtikar menjadi hal yang dilarang apabila ada yang menimbun, sehingga manusia kesulitan mendapatkannya.

\section{e. Gharar}

Menurut bahasa Arab makna al-gharar adalah al-khathr (pertaruhan). Sehingga Ibnu Taimiyyah menyatakan, al-gharar adalah yang tidak jelas hasilnya (majhul al-'aqibah). Sedangkan menurut As-Sa'di, algharar adalah al-mukhatharah (pertaruhan) dan al-jahalah (ketidak jelasan). Perihal ini masuk dalam kategori perjudian.

Berdasarkan pengertian ini dapat diambil pengertian bahwa yang dimaksud jual beli gharar adalah,semua jual beli yang mengandung ketidakjelasan, pertaruhan, atau perjudian. Dalam sistem jual beli gharar ini terdapat unsur memakan harta orang lain secara batil.

\section{f. Menjual Barang Yang Dilarang Dalam Islam}

Halal dan haram adalah persoalan prinsipil. Memperdagangkan atau melakukan transaksi barang yang haram, misalnya alkohol, obat-obatan terlarang dan barang-barang lain yang dilarang dalam Islam. Segala sesuatu yang Allah haramkan terlarang untuk diperjual belikan

Jika terjadi transaksi terhadap komoditas yang diharamkan dalam Islam maka seluruh pihak yang terlibat transaksi ikut menanggung dosa, 
sebagaimana disebutkan dalam firman Allah berikut ini: dan janganlah kalian tolong menolong dalam dosa dan pelanggaran. (Al Maidah: 2)

Semua pekerjaan yang diperoleh dengan jalan haram adalah dosa. Setiap daging yang tumbuh dari dosa para pihak yang terlibat dalam memperdagangkan barang-barang haram ini tidak dapat diselamatkan, sebab pokok perdagangannya itu sendiri sudah mungkar yang ditentang dan tidak dibenarkan oleh Islam dengan jalan apapun.

\section{g. Najsy}

Najsy adalah bentuk aktivitas perniagaan yang dilarang dalam ajaran Islam, najsy merupakan salah satu upaya penjual untuk menaikkan harga tawaran barang. Najasy adalah bentuk praktek jual-beli yang dilarang oleh Islam, hal ini disampaikan oleh Nabi Muhammad dalam hadis berikut ini: Janganlah kamu sekalian melakukan jual-beli dengan cara najasy. (HR. Al-Bukhari)

Najasy merupakan hal yang dilarang oleh Allah dalam praktek bisnis, maka bilamana praktek najasy ini dilakukan, jual beli tersebut tidak halal. Najsy dilakukan dengan melibatkan pihak ketiga yang sebenarnya tidak mempunyai keinginan untuk membeli barang tersebut. Hal ini bertujuan untuk menguntungkan penjual secara sepihak, karena pembeli dirugikan dengan membeli barang tersebut harga yang tinggi.

\section{Konsep CSR Dalam Islam}

CSR berkaitan erat dengan etika bisnis oleh karena itu konsep CSR dalam Islam juga berkaitan dengan konsep etika bisnis dalam Islam, paradigma Islam tentang etika bisnis adalah adanya konsepsi hubungan manusia dengan Tuhan, manusia dengan manusia lain dan manusia dengan lingkungannya. Konsep ini sejalan dengan triple bottom line CSR (3P) yang terdiri dari tiga komponen penting sustainable development, 3P merupakan singkatan dari profit, planet dan people. 
Konsep hubungan manusia ini dalam Islam dikenal dengan istilah hablumminallah wa hablumminannas merupakan landasan filosofis yang harus dibangun dalam pribadi Muslim. Hablumminallah maupun hablumminannas adalah dua aspek yang tidak dapat dipisahkan, kedua hubungan tersebut harus berjalan dengan seimbang dimana hubungan sesama manusia tidak boleh bertentangan dengan hubungan kita kepada Allah.

Hablumminallah adalah amalan-amalan yang termasuk persoalan ibadah, contohnya sholat, puasa, zakat, haji, membaca Al Qur'an, doa, zikir, tahlil, shalawat dan lain-lain. Hablumminnas (hubungan manusia dengan manusia) merupakan salah satu kewajiban bagi Muslim yang diperintahkan Allah SWT sebagai upaya kita menjalin hubungan antara manusia.

Allah menurunkan syariat tidak hanya berisi aturan untuk beribadah, tetapi juga untuk mengatur hubungan sesama manusia. Islam mengatur banyak hal tentang urusan antar sesama manusia. Mulai dari perkara jual beli, pinjam meminjam, sewamenyewa, pembagian warisan, hukuman untuk tindakan kriminal, pernikahan dan banyak hal yang menyangkut urusan manusia.

Bisnis dalam Islam memiliki posisi yang sangat mulia sekaligus strategis kerena bukan sekedar diperbolehkan di dalam Islam, melainkan justru diperintahkan oleh Allah SWT di dalam Al-Quran. Bisnis dalam perspektif ekonomi Islam bersifat universal, Kepemilikan, pemanfaatan dan pelaksanaannya dapat dilakukan oleh siapapun tanpa sekat agama, kepercayaan, ras, suku dan bahasa. Kegiatan bisnis merupakan bagian dari pelaksanaan peran manusia sebagai khalifah dalam rangka memakmurkan bumi berdasarkan petunjuk Allah sekaligus sebagai ibadah kepada Allah.

Pelaksanaan kegiatan memakmurkan bumi harus tetap menjaga keseimbangan dan keharmonisan semesta secara fisik dan sosial, lahir maupun batin. Penegakan iman dan takwa diwujudkan setiap aspek dan kegiatan usaha dengan memperhatikan hubungan baik yang komprehensif mencakup seluruh 
kepentingan stakeholder termasuk lingkungan sekitar. Pelaksanaan kegiatan bisnis ditujukan untuk menciptakan dan memelihara kebaikan bagi semua, sebagaimana tujuan dari Islam adalah terwujudnya keberkahan dan kasih sayang bagi semesta alam (rahmatan lil alamin).

Kedudukan manusia dalam bisnis secara kodrat tidak terlepas dari kecenderungan untuk berperilaku baik dan buruk, terlebih lagi manusia yang beraktifitas di dunia bisnis. Pelaku bisnis dapat melakukan aktivitas bisnisnya dengan cara yang tidak baik untuk mencapai tujuannya, namun disisi lain tidak menutup kemungkinan adanya pelaku bisnis yang tetap mampu mempertahankan perilaku baiknya dalam bisnis. Bisnis yang dipandu oleh spiritualitas dan etika akan menciptakan iklim usaha yang sehat dan berkesinambungan dengan terwujudnya tata kelola perusahaan yang baik.

Di dunia bisnis saat ini telah bekembang teori dan pedoman good corporate governance (GCG), demikian juga dalam Al Qur'an dan Hadis tercantum pedomanpedoman untuk melaksanakan bisnis dengan baik dan benar. Berdasarkan kajian, asas GCG dan aspek-aspek lain dari GCG mempunyai landasan dalam Al Qur'an dan Hadis. Secara operasional bisnis dalam Islam dapat mengacu pada dua asas, asas pertama adalah sifat dan perilaku nabi dan rasul dalam beraktifitas termasuk dalam berbisnis yaitu shiddiq, fathonah, amanah, dan tabligh (nubuah). Ke empat sifat ini memiliki kandungan pengertian antara lain:

a) Shiddiq berarti benar, yaitu senantiasa menyatakan dan melakukan kebenaran dan kejujuran dimanapun berada dan kepada siapapun. Implikasinya dalam berbisnis adalah tegaknya kejujuran dan menghindari semua bentuk penipuan dan penggelapan.

b) Fathanah berarti cerdas, yaitu mampu berpikir secara jernih dan rasional serta mengambil keputusan dengan cepat dan tepat. Dalam dunia bisnis sifat fatanah ini digunakan untuk mengidentifikasi dan menetapkan hal-hal dan atau kegiatan yang diperbolehkan atau tidak. 
c) Amanah berarti dapat dipercaya, yaitu menjaga kepercayaan yang diberikan oleh Allah dan orang lain. Dalam berbisnis, pemberian kepercayaan ini diwujudkan dalam berbagai bentuk pertanggungjawaban dan akuntabilitas atas kegiatan-kegiatan bisnis.

d) Tabligh berarti menyampaikan yaitu menyampaikan wahyu dari Allah tentang kebenaran yang harus ditegakkan di muka bumi.

Keempat sifat ini merupakan satu kesatuan yang tidak dapat dipisahkan satu dengan yang lainnya yang merupakan salah satu perwujudan dari iman dan takwa. Dari keempat kesatuan sifat Nabi Muhammad SAW sejalan dengan asas GCG yang berlaku secara umum dalam dunia usaha yaitu transparansi, akuntabilitas, responsibilitas, independensi serta kewajaran dan kesetaraan (fairness).

\section{a. Transparansi atau Keterbukaan}

Transparansi secara sederhana bisa diartikan sebagai keterbukaan informasi, dalam mewujudkan prinsip ini, perusahaan dituntut untuk menyediakan informasi yang cukup, akurat, tepat waktu kepada segenap stakeholders. Tranparansi mengandung unsur pengungkapan dan penyediaan informasi yang memadai dan mudah diakses oleh pemangku kepentingan. Transparansi diperlukan agar pelaku bisnis menjalankan bisnis secara objektif dan sehat. Pelaku bisnis harus mengambil inisiatif untuk mengungkapkan tidak hanya masalah yang disyaratkan oleh peraturan perundangan, tetapi juga hal yang penting untuk pengambilan keputusan.

\section{b. Akuntabilitas}

Akuntabilitas berarti adanya kejelasan fungsi, struktur, sistem dan pertanggungjawaban elemen perusahaan. Apabila prinsip ini diterapkan secara efektif, maka akan ada kejelasan akan fungsi, hak, kewajiban, dan wewenang serta tanggung jawab antara pemegang saham, dewan komisaris, dan dewan direksi. Akuntabilitas merupakan asas penting dalam bisnis juga diatur dalam 
Islam sebagaimana tercermin dalam Surat Al Isra Ayat 36 yang artinya, dan janganlah kaти mengikuti apa yang kaтu tidak mempunyai pengetahuan tentangnya. Sesungguhnya pendengaran, penglihatan dan hati, semuanya itu akan diminta pertanggungan jawabnya. Akuntabilitas mengandung unsur kejelasan fungsi dalam organisasi dan cara mempertanggungjawabkannya, pelaku bisnis harus dapat mempertanggungjawabkan kinerjanya secara transparan dan wajar.

\section{c. Independensi}

Prinsip ini mensyaratkan agar perusahaan dikelola secara profesional tanpa ada benturan kepentingan dan tekanan atau intervensi dari pihak manapun yang tidak sesuai dengan peraturan yang berlaku sebagaimana dinyatakan Allah dalam firmanNya: Sesungguhnya orang-orang yang mengatakan, "Rabb kami ialah Allah", kemudian mereka meneguhkan pendirian mereka, maka malaikat akan turun kepada mereka (dengan mengatakan): "Janganlah kamu merasa takut dan janganlah kaтu merasa sedih; dan bergembiralah kamu dengan (memperoleh) surga yang telah dijanjikan Allah kepadamu”. (QS. Fushshilat Ayat 30)

Independensi terkait dengan konsistensi yaitu tetap berpegang teguh pada kebenaran meskipun harus menghadapi risiko, sikap ini ditunjukan dengan sikap yang mampu menyerap informasi,(mendengar perkataan) dan mengambil keputusan (mengikuti) yang terbaik (sesuai dengan nuraninya tanpa tekanan pihak manapun).

\section{d. Kewajaran dan kesetaraan (fairness)}

Kewajaran dan kesetaraan (fairness) mengandung unsur kesamaan perlakuan dan kesempatan sebagaimana Allah berfirman dalam Surat Al-Maidah Ayat 8 yang artinya: Wahai orang-orang yang beriman hendaklah kamu menjadi orang yang selalu menegakkan kebenaran karena Allah, menjadi saksi 
dengan adil. Janganlah sekali-kali kebencianmu terhadap orang (golongan) lain menyebabkan kamu tidak berlaku adil. berlaku adillah kamu karena adil itu lebih dekat kepada takwa. Dan bertakwalah kepada Allah karena Allah Maha Mengetahui apa yang kalian kerjakan. (QS. Al-Maidah Ayat 8)

Fairness atau kewajaran merupakan salah satu wujud keadilan dalam dunia bisnis. Setiap keputusan bisnis, baik dalam skala individu maupun lembaga, hendaklan dilakukan sesuai kewajaran dan kesetaraan sesuai dengan apa yang biasa berlaku, dan tidak diputuskan berdasarkan suka atau tidak suka.

\section{e. Responsibility (pertanggungjawaban)}

Pertanggungjawaban perusahaan adalah kepatuhan perusahaan terhadap peraturan yang berlaku, diantaranya termasuk masalah pajak, hubungan industrial, kesehatan dan keselamatan kerja, perlindungan lingkungan hidup, memelihara lingkungan bisnis yang kondusif bersama masyarakat dan sebagainya.

Tanggungjawab atas perbuatan manusia dilakukan baik di dunia maupun di akhirat yang semuanya direkam dalam catatan yang akan dicermatinya nanti sebagaimana firman Allah dalam surat Al Isra Ayat 14 yang artinya: Bacalah kitabmu (laporan pertanggungjawabanmu), сukuplah kamu pada waktu itu mengevaluasi dirimu sendiri. Dengan pertanggungjawaban ini maka kegiatan bisnis yang dijalankan dapat terpelihara kesinambungannya dalam jangka panjang dan mendapat pengakuan sebagai pelaku bisnis yang baik (good corporate citizen).

Berdasarkan prinsip ini, pelaku bisnis harus berpegang pada prinsip kehati-hatian dan memastikan kepatuhan terhadap ketentuan bisnis dan perundangan-undangan, anggaran dasar serta peraturan internal pelaku bisnis.

Pelaku bisnis harus melaksanakan isi perjanjian yang dibuat termasuk tetapi tidak terbatas pada pemenuhan hak dan kewajiban yang disepakati oleh para 
pihak. Prinsip ini juga terkait dengan pelaksanaan CSR, dimana pelaku bisnis harus melaksanakan tanggung jawab sosial. Bentuk pelaksanaan CSR antara lain dengan peduli terhadap masyarakat dan kelestarian lingkungan terutama di sekitar tempat berbisnis dengan membuat perencanaan dan pelaksanaan yang memadai. Pelaksanaan tanggung jawab sosial tersebut dapat dilakukan dengan cara membayar zakat, infak dan sadaqah.

Penerapan CSR merupakan salah satu implementasi etika bisnis, CSR merupakan hal yang menentukan dalam mempertahankan eksistensi suatu perusahaan. Pemikiran yang mendasari CSR merupakan inti dari Etika Bisnis karena perusahaan tidak hanya mempunyai kewajiban-kewajiban ekonomis dan legal tetapi juga kewajiban-kewajiban terhadap pihak-pihak yang berkepentingan (stakeholders), karena perusahaan tidak bisa hidup, beroperasi dan memperoleh keuntungan tanpa bantuan pihak lain. CSR merupakan pengambilan keputusan Perusahaan yang dikaitkan dengan nilai-nilai etika, dapat memenuhi kaidah-kaidah dan keputusan hukum dan menjunjung tinggi harkat manusia, masyarakat dan lingkungan.

Konsep responsibility (tanggung jawab) dan fairness (keadilan) merupakan prinsip-prinsip etika yang diimplementasikan dalam wujud CSR. Oleh sebab itu, mengkaji konsep CSR berarti membahas konsep tanggung jawab (responsibility) perusahaan dan perwujudan keadilan (fairness) sebagai etika bisnis. Responsibility atau pertanggungjawaban adalah kepatuhan perusahaan terhadap ketentuan/hukum yang berlaku, di antaranya termasuk masalah pajak, hubungan industrial, kesehatan dan keselamatan kerja, perlindungan lingkungan hidup, memelihara lingkungan bisnis yang kondusif bersama masyarakat dan sebagainya.

CSR dalam perspektif Islam harus dapat menjadi konsep yang menawarkan keseimbangan kepentingan antara shareholders dan stakeholders. Secara teoretik CSR dapat didefinisikan sebagai tanggung jawab moral perusahaan dengan atau tanpa aturan hukum sebuah perusahaan harus menjunjung tinggi moralitas. Prinsip- 
prinsip dasar dalam etika bisnis Islam pertama kali dirumuskan oleh An-Naqvi dalam bukunya Ethics and Economics: An Islamic Synthesis (1981). Rumusan AbNaqvi ini selanjutnya banyak dikutip oleh para penulis kontemporer tentang ekonomi Islam di dunia, empat prinsip (aksioma) etika bisnis Islam ini dapat diterapkan dalam sebagai konsep CSR terdiri dari tauhid (unity/kesatuan), keseimbangan atau kesejajaran (equilibrium), kehendak bebas (free will), dan tanggung jawab (responsibility).

\section{a. Tauhid (unity)}

Tauhid merupakan konsep serba eksklusif dan serba inklusif, pada tingkat absolut konsep ini membedakan sang khalik dengan makhlukNya yang memerlukan penyerahan tanpa syarat kepada kehendakNya. Tetapi pada eksistensi manusia memberikan suatu prinsip perpaduan yang kuat sebab seluruh umat manusia dipersatukan dalam ketaatan kepada Allah semata, konsep tauhid merupakan dimensi vertikal Islam sekaligus horizontal yang memadukan segi politik, sosial ekonomi.

Sumber utama etika Islam adalah kepercayaan penuh dan murni terhadap kesatuan Tuhan, prinsip ini menunjukkan dimensi vertikal Islam yang menghubungkan institusi-institusi sosial yang terbatas dan tak sempurna dengan zat yang sempurna (Tuhan) dan tak terbatas.

Keesaan seperti dicerminkan dalam konsep tauhid merupakan dimensi vertikal Islam, konsep keesaan Tuhan menggabungkan semua aspek kehidupan seorang Muslim, baik ekonomi, politik, agama, sosial dan masyarakat. Prinsip ini menekankan pada gagasan mengenai konsistensi dan keteraturan, prinsip ini memiliki pengaruh yang paling mendalam terhadap diri seorang Muslim.

Aksioma ini memberikan konsep bahwa Allah menetapkan batas-batas tertentu atas perilaku manusia untuk memberikan manfaat tanpa ada yang merasa dirugikan dengan menaati ajaran Islam. Atas dasar pandangan konsep 
tersebut, maka etika dan ekonomi atau etika dan bisnis menjadi terpadu, vertikal maupun horizontal, membentuk suatu persamaanyang sangat penting dalam sistem Islam. Berpijak prinsip ini seorang Muslim dalam melakukan aktivitas bisnisnya tidak akan melakukan praktek bisnis yang dilarang oleh Allah, baik secara terpaksa atau tidak.

\section{b. Keseimbangan Atau Kesejajaran (Equilibrium)}

Keseimbangan atau 'adl menggambarkan dimensi horisontal ajaran Islam, dan berhubungan dengan harmoni segala sesuatu di alam semesta. Sifat keseimbangan ini lebih dari sekedar karakteristik alam, sifat ini harus ditanamkan oleh setiap Muslim dalam kehidupannya. Keseimbangan berarti bahwa perilaku bisnis harus seimbang dan adil, keseimbangan berarti tidak berlebihan dalam mengejar keuntungan ekonomi. Pada struktur ekonomi dan bisnis harus menghindari pemusatan kekuasaan ekonomi dan bisnis pada segelintir orang, konsisten dalam distribusi pendapatan dan kekayaan. Seorang Muslim harus memenuhi keseimbangan nilai yang sama antara nilai sosial dan individual dalam masyarakat, kebahagiaan individu harus mempunyai nilai yang sama dipandang dari sudut sosial.

Bisnis Islam tidak mengakui adanya, baik hak milik yang tidak terbatas maupun sistem pasar yang bebas tak terkendali. Hal ini disebabkan karena ekonomi dan bisnis dalam pandangan Islam bertujuan bagi penciptaan keadilan sosial. Keseimbangan dan keadilan dalam Islam juga berarti kepemilikan individu dalam Islam bersifat terbatas dan harta mempunyai fungsi sosial.

Keadilan adalah salah satu prinsip yang sangat ditekankan dalam Islam, tuntunan dan aturan Islam dibangun di atas dasar keadilan dan seluruh Muslim diperintahkan untuk berlaku adil. Dalam beraktivitas di dunia bisnis, Islam mengharuskan untuk berbuat adil, tak terkecuali pada pihak yang tidak disukai dan tidak membedakan kedudukan seseorang berdasarkan agama, ras, suku dan kekayaan (non diskriminatif). 


\section{c. Kehendak bebas (Free Will)}

Manusia sebagai khalifah sampai batas-batas tertentu mempunyai kehendak bebas untuk mengarahkan kehidupannya kepada tujuan yang akan dicapainya. Manusia dianugerahi kehendak bebas (free will) untuk membimbing kehidupannya sebagai khalifah. Berdasarkan aksioma kehendak bebas ini, dalam bisnis manusia mempunyai kebebasan untuk membuat suatu perjanjian atau tidak, melaksanakan bentuk aktivitas bisnis tertentu, berkreasi mengembangkan potensi bisnis yang ada.

Kehendak bebas atau kebebasan berkaitan dengan penentuan sikap seorang Muslim terhadap pilihan-pilihan, karena terdapat dua konsekuensi yang melekat. Di satu sisi ada niat dan konsekuensi buruk yang dapat dilakukan, tetapi di sisi lain ada niat dan konsekuensi baik. Pilihan antara baik dan buruk adalah bentuk resiko yang bakal berdampak pada pahala dan dosa.

Manusia mempunyai suatu potensi dalam menentukan pilihan-pilihan yang beragam, karena kebebasan manusia tidak dibatasi. Tetapi dalam kehendak bebas yang diberikan Allah kepada manusia haruslah sejalan dengan prinsip dasar diciptakannya manusia yaitu sebagai khalifah di bumi. Sehingga kehendak bebas itu harus sejalan dengan kemaslahatan kepentingan individu telebih lagi pada kepentingan umat.

\section{d. Tanggung Jawab (Responsibility)}

Kebebasan tanpa batas adalah suatu hal yang mustahil dilakukan oleh manusia karena tidak menuntut adanya pertanggungjawaban dan akuntabilitas untuk memenuhi tuntunan keadilan dan kesatuan, manusia perlu mempertanggungjawabkan tindakannya. Kebebasan yang dimiliki manusia dalam menggunakan potensi sumber daya memiliki batas-batas tertentu, dan tidak digunakan sebebas-bebasnya, melainkan dibatasi oleh ketentuan hukum, norma-norma dan etika yang tertuang dalam Al Qur'an dan hadis. Segala 
tuntunan ini harus dipatuhi dan dijadikan acuan atau landasan dalam menggunakan potensi sumber daya yang dikuasai, sumber daya yang dimiliki harus digunakan hanya untuk melakukan kegiatan bisnis yang diperbolehkan. Pengelolaan bisnis harus juga dilakukan dengan cara-cara yang benar, adil dan mendatangkan manfaat optimal bagi semua pihak yang terlibat dalam kegiatan bisnis yang dilakukan.

Secara logis prinsip ini berhubungan erat dengan kehendak bebas, Allah menetapkan batasan mengenai hal yang bebas dilakukan oleh manusia. Manusia sebagai pelaku bisnis mempunyai tanggung jawab moral kepada Allah atas perilaku bisnis, demikian juga harta merupakan amanah Allah yang harus dipertanggungjawabkan. Tanggung jawab (responsibility) terkait erat dengan konsekuensi seorang Muslim atas segala aktifitas yang dilakukan kepada Tuhan dan kepada manusia sebagai masyarakat. Karena manusia hidup tidak sendiri dia tidak lepas dari hukum yang dibuat oleh manusia itu sendiri sebagai komunitas sosial. Dalam bidang ekonomi dan bisnis, prinsip ini dijabarkan menjadi suatu pola perilaku tertentu. Pertanggungjawaban terfokus baik pada individual maupun sosial yang kedua-duanya harus dilakukan secara seimbang.

\section{e. Benovelence/Ihsan (Kebenaran/Kebajikan)}

Menurut Beekun terdapat lima (5) aksioma dalam ekonomi islam, prinsip yang ke lima adalah benovelence atau dalam istilah lebih familiar dikenal dengan Ihsan Ihsan adalah kehendak untuk melakukan kebaikan hati dan meletakkan bisnis pada tujuan untuk berbuat kebaikan sebagai bentuk ibadah kepada Allah. Kebenaran dalam konteks ini selain mengandung makna kebenaran, terkandung dua unsur yaitu kebajikan dan kejujuran.

Menurut konteks bisnis kebenaran dimaksudkan sebagai niat, sikap dan perilaku benar dalam upaya untuk meraih keuntungan. Berpegang pada prinsip kebenaran ini maka etika bisnis Islam sangat menjaga dan berlaku preventif terhadap kemungkinan adanya kerugian salah satu pihak dalam melakukan 
transaksi, kerjasama atau perjanjian bisnis. Bentuk kebajikan dalam bisnis adalah sikap kerelaan yang berkaitan erat dengan sikap jujur. Kerelaan diartikan sebagai kesediaan para pihak dalam transaksi, kerjasama atau perjanjian bisnis yang dilakukan dengan jujur. Kejujuran dilaksanakan dalam setiap proses bisnis yang dilakukan tanpa unsur penipuan, hal ini bertujuan untuk menciptakan dan menjaga keharmonisan hubungan antara pelaku bisnis maupun masyarakat.

Kerangka konsep CSR dalam Islam dapat digambarkan melalui diagram berikut ini:

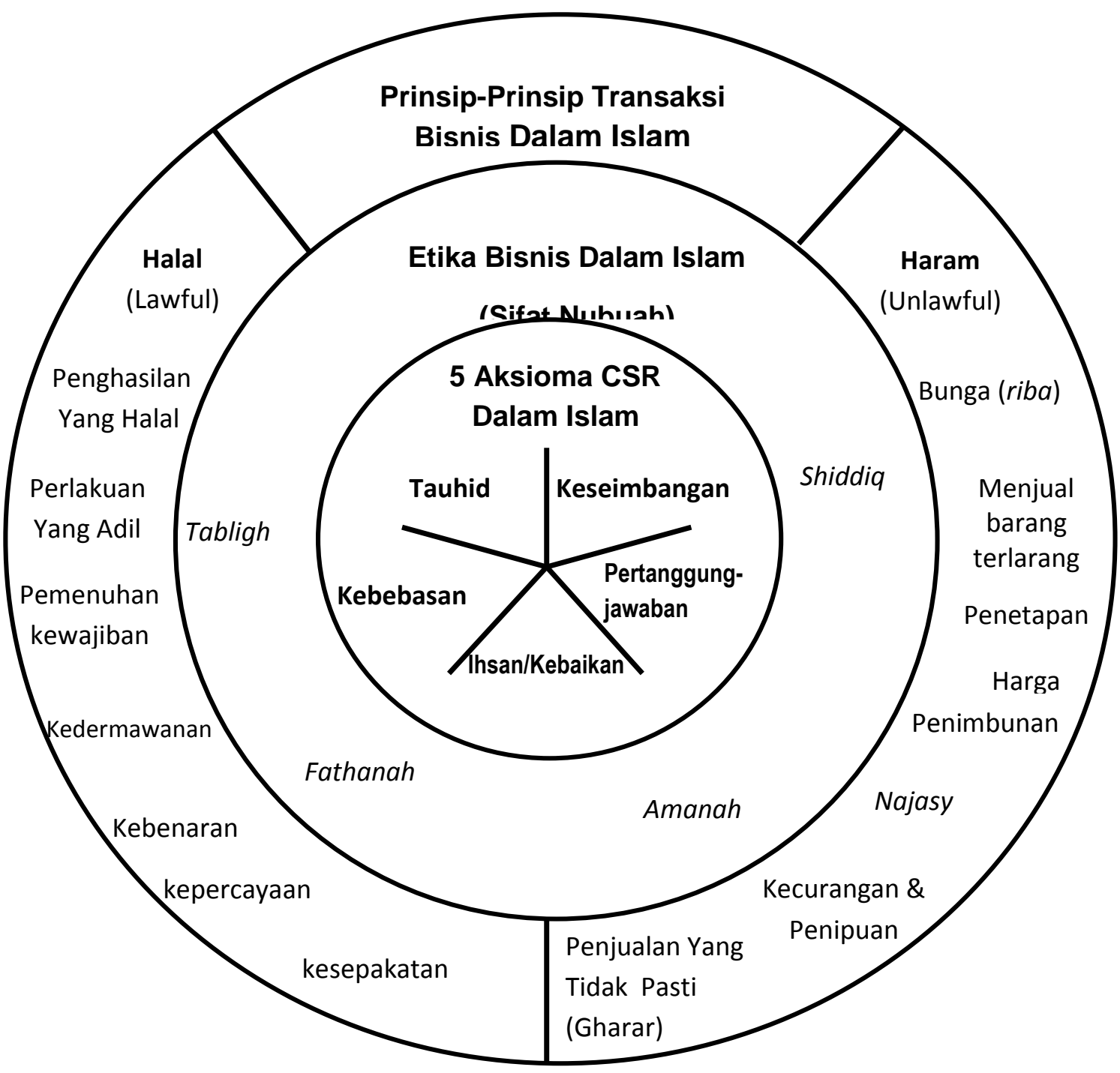




\section{Kerangka konsep CSR dalam Islam}

Lingkaran pertama pada diagram di atas menggambarkan lima aksioma sistem etika yang terdiri dari tauhid, keseimbangan, kehendak bebas dan pertanggungjawaban yang merupakan inti dari sistem etika Islam. Aksioma ini adalah prinsip dasar dari setiap sistem ekonomi dan sosial Islam, aksioma-aksioma tersebut dapat dikembangkan menjadi kerangka konsep CSR dalam Islam.

Lingkaran kedua mencakup unsur-unsur Islam etika Islam yang telah diturunkan dari prinsip utama dalam Islam yaitu tauhid, unsure-unsur tersebut adalah sifat nabi Muhammad (nubuah) yang terdiri dari shiddiq, fathanah, amanah dan tabligh. Sifat nubuah lebih menngambarkan etika bisnis dalam Islam, karena telah diajarkan Nabi Muhammad dalam kehidupan sehari-hari, termasuk dalam menjalankan kegiatan bisnis.

Lingkaran terluar mewakili unsur-unsur transaksi bisnis yang sesuai dengan yurisprudensi Islam (fiqih), konsep mengenai hal-hal yang dianjurkan (halal) dan hal-hal yang dilarang (haram) memberikan pedoman dan batasan yang jelas untuk transaksi bisnis dalam Islam. Bisnis Islami ialah serangkaian aktivitas bisnis dalam berbagai bentuknya yang tidak dibatasi oleh jumlah kepemilikan (barang/jasa), 
namun dibatasi dalam cara memperolehnya dan pendayagunaan hartanya karena aturan halal dan haram. Batasan Islam mengenai kegiatan bisnis ini didasarkan pada sistem etika Islam (nubuah) yang diajarkan oleh Nabi Muhammad dan berasal dari prinsip tauhid.

Islam mempunyai prinsip pertanggungjawaban yang seimbang dalam segala bentuk dan ruang lingkup kehidupan. Seorang Muslim diwajibkan untuk menyeimbangkan berbagai kepentingan dalam kehidupannya, antara jiwa dan raga, antara individu dan sosial serta antara suatu masyarakat dengan masyarakat yang lain. Semua elemen dari tiga lingkaran yang disajikan dalam diagram sebelumnya saling berhubungan untuk membentuk suatu kerangka konsep CSR dalam Islam. Diagram menggambarkan kerangka konseptual CSR dalam Islam yang juga menjadi konsep dasar dari suatu sistem sosial dan ekonomi Islam yang bersifat komprehensif serta seimbang.

\section{B.2. Penerapan Prinsip-Prinsip Islam Dalam Pengaturan Corporate Social Responsibility Di Indonesia}

\section{Konsep CSR Secara Global}

Secara global standar CSR dikenal dengan nama ISO 26000 Guidance on Social Responsibility. CSR adalah tanggung jawab sebuah organisasi terhadap dampak-dampak dari keputusan-keputusan dan kegiatan-kegiatannya pada masyarakat dan lingkungan yang diwujudkan dalam bentuk perilaku transparan dan etis yang sejalan dengan pembangunan berkelanjutan dan kesejahteraan masyarakat; mempertimbangkan harapan pemangku kepentingan, sejalan dengan hukum yang ditetapkan dan norma-norma perilaku internasional; serta terintegrasi dengan organisasi secara menyeluruh.

Konsep 3P yang terdiri dari profit, people dan planet, bisa dipadukan dengan komponen dalam ISO 26000. Konsep keuntungan, selain mendapatkan 
keuntugan untuk perusahaan tetapi juga harus mencakup tata kelola perusahaan yang baik dan praktek bisnis yang etis. Konsep planet atau lingkungan, jelas berkaitan dengan pemeliharaan dan pelestarian lingkungan. Konsep masyarakat bisa merujuk pada konsep pembangunan masyarakat yang tidak hanya menyangkut kesejahteraan ekonomi masyarakat (seperti pemberian modal usaha dan pelatihan keterampilan kerja). Tetapi juga, kesejahteraan sosial (contohnya, pemberian jaminan sosial, penguatan akses masyarakat terhadap pelayanan kesehatan dan pendididikan).

CSR selalu mengacu pada kenyataan bahwa tanggung jawab sosial perusahaan merupakan bagian penting dari strategi bisnis yang berkaitan erat dengan keberlangsungan usaha dalam jangka panjang. Tanggung jawab sosial lingkungan terkait dengan unsur sustainability (pembangunan keberlanjutan) yang dilakukan oleh perusahaan dalam meningkatkan kualitas hidup perusahaan, lingkungan maupun sosial komunitas setempat. Berpijak dari berbagai macam konsep dan definisi CSR yang telah diuraikan di atas, kegiatan CSR dapat dibagi ke dalam empat dimensi atau bidang antara lain sebagai berikut:

a) dimensi lingkungan;

b) dimensi sumber daya manusia;

c) dimensi kemanusiaan; dan

d) dimensi hak asasi manusia

\section{Pengaturan Corporate Social Responsibility Di Indonesia}

\section{a. Undang-Undang No. 40 Tahun 2007}

Dalam UU PT, CSR diatur pada Pasal 1 ayat (3) dan Pasal 74 ayat (1), (2), (3), dan (4) yang intinya adalah bahwa PT yang menjalankan kegiatan usahanya di bidang dan/atau berkaitan dengan sumber daya alam wajib melaksanakan tanggung 
jawab sosial dan lingkungan. Kewajiban pelaksanaan CSR bagi perusahaan yang menjalankan kegiatan usahanya di bidang dan/atau berkaitan dengan sumber daya alam, tidak hanya melihat dari bidang kegiatan usaha perusahaan, sehingga walaupun perusahaan tersebut tidak secara langsung melakukan eksploitasi sumber daya alam, tetapi selama kegiatan usaha perusahaan berdampak pada fungsi kemampuan sumber daya alam, maka wajib untuk melaksanakan CSR. Hal ini berarti bahwa semua PT wajib melaksanakan CSR yang dianggarkan dan diperhitungkan sebagai biaya perseroan yang pelaksanaannya dilakukan dengan memperhatikan kepatutan dan kewajaran.

Menurut UU PT perusahaan harus menjabarkan pelaksanaan kegiatan CSR, pengungkapan CSR yang dilakukan perusahaan ini memang sudah diatur dalam Pasal 66 ayat (1) dan ayat (2) huruf c, pengungkapan tersebut dengan cara dicantumkan dalam laporan tahunan perusahaan.

\section{b. Undang-Undang No. 25 Tahun 2007 Tentang Penanaman Modal}

Pasal dalam Undang-Undang No. 25 Tahun 2007 tentang Penanaman Modal yang mengatur terkait CSR, yaitu Pasal 15 dan Pasal 16. Pasal 15 UU No. 25 Tahun 2007 ini menegaskan bahwa dalam melaksanakan penanaman modal baik terhadap pihak penanaman modal asing maupun lokal berkewajiban memperhatikan prinsip tata kelola perusahaan yang baik (GCG) dan juga harus melaksanakan tanggung jawab sosial perusahaan (CSR) dengan demikian prinsip GCG dan CSR dalam hal penanaman modal bukan lagi perupakan suatu tanggung jawab moral tetapi sudah merupakan kewajiban hukum dengan demikian jika hal ini tidak dilaksanakan dengan baik memiliki dampak hukum yaitu berupa pemberian sanksi berupa peringatan tertulis, pembatasan kegiatan usaha, pembekuan kegiatan usaha dan/atau fasilitas penanaman modal atau pencabutan kegiatan usaha dan/atau fasilitas penanaman modal.

\section{c. Undang-Undang Nomor 19 Tahun 2003}


Undang-Undang No. 19 Tahun 2003 tentang BUMN yang mengatur CSR secara lebih terperinci. Dalam UU BUMN dinyatakan bahwa selain mencari keuntungan, peran BUMN adalah juga memberikan bimbingan bantuan secara aktif kepada pengusaha golongan lemah, koperasi dan masyarakat. Undang-undang ini kemudian dijabarkan lebih jauh oleh Peraturan Menteri Negara BUMN No. 5 Tahun 2007 yang mengatur mulai dari besaran dana hingga tata cara pelaksanaan CSR, dimana CSR dilaksanakan dalam bentuk program kemitraan dan bina lingkungan (PKBL).

Seluruh BUMN diwajibkan melaksanakan PKBL sebagai wujud kepedulian terhadap pertumbuhan ekonomi masyarakat serta kondisi lingkungan sosial masyarakat sekitar, BUMN melaksanakan PKBL sebagai bagian dari kegiatan perusahaan. Dari perspektif bisnis, PKBL merupakan wujud kepedulian sosial terhadap masyarakat dan lingkungan sekitarnya atau CSR. Sebenarnya CSR telah dilakukan terlebih dahulu oleh BUMN sebelum adanya UU PT tetapi dengan istilah PKBL.

Pengaturan PKBL relatif lebih terperinci dibandingkan CSR dalam UU PT. Hal ini dikarenakan PKBL telah memiliki aturan pelaksana atau teknis, sedangkan UU PT belum ada peraturan teknis pelaksanaan. Maka dari perbandingan peraturan antara CSR terdapat perbedaan teknis pelaksanaan CSR pada UU PT, sehingga ketentuan PKBL pada BUMN, harus disesuaikan dengan ketentuan Pasal 74 UU PT.

\section{d. Undang-Undang No. 23 Tahun 1997 Tentang Pengelolaan Lingkungan Hidup}

Perwujudan untuk pemenuhan hak atas lingkunagn hidup yaitu dengan munculnya UU No. 4 tahun 1982 tentang Ketentuan Pokok Pengelolaan Lingkungan Hidup yang telah diubah dengan UU No. 23 tahun 1997 tentang Pengelolaan Lingkungan hidup. Apabila dikaitkan dengan maka hak atas lingkungan memang harus dipenuhi oleh perusahaan. Hal tersebut sesuai dengan Pasal-Pasal yang menyangkut CSR, yaitu Pasal 5 ayat (1) dan Pasal 20 ayat (1) . 
Dari pasal-pasal diatas tampak bahwa masalah lingkungan juga merupakan tanggung jawab sosial bagi perusahaan-perusahaan sebagai legal entity untuk mempertahankan esistensinya dan sudah selayaknya mengimplementasikan apa yang menjadi tujuan sosial perusahaannya. Selain itu dengan diaturnya hak atas lingkungan dalam perundang-undangan nasional maka sebagai konsekuensinya adalah hak tersebut memberikan kepada yang mempunyai suatu tuntutan yang sah guna meminta kepentingannya akan suatu lingkungan hidup yang sehat dan dihormati, suatu tuntutan yang dapat didukung oleh prosedur hukum oleh pengadilan dan perangkat lainnya.

\section{Penerapan Prinsip-Prinsip Islam Dalam Pengaturan CSR Di Indonesia}

Islam menempatkan aspek ekonomi dan tanggung jawab sosial dalam kedudukan yang setara, kedua aspek tersebut harus diatur agar masing-masing dari mendapatkan bagiannya secara benar. Islam mempunyai prinsip pertanggungjawaban yang seimbang dalam segala bentuk dan ruang lingkupnya yang terintegrasi pada semua bidang kehidupan antara lain agama, ekonomi, dan sosial-politik-budaya. Konsep kesimbangan ini juga terkait antara jiwa dan raga, antara individu dan keluarga, antara individu dan sosial dan suatu masyarakat dengan masyarakat yang lain.

CSR dalam perspektif Islam merupakan konsep yang menawarkan keseimbangan kepentingan antara shareholders dan stakeholders, keseimbangan antara aspek ekonomi dan sosial ini dapat dilihat dalam prinsip-prinsip Islam. Prinsip-prinsip dasar dalam etika bisnis Islam yang dapat dijadikan sebagai konsep, yaitu tauhid (unity/kesatuan), keseimbangan atau kesejajaran (equilibrium), kehendak bebas (free will), dan tanggung jawab (responsibility). Prinsip-prinsip ini sejalan dengan konsep CSR, karena pada dasarnya segala aktifitas bisnis dilihat sebagai salah satu bentuk ibadah kepada Allah SWT.

CSR di Indonesia merupakan hal yang baru, kedudukan mengenai CSR ini semakin menguat terutama setelah dinyatakan dengan tegas dalam UU PT 
yang terdapat pada Pasal 1 angka (3) dan Pasal 74 yang belum diatur UU PT yang terdahulu. Melihat perkembangan CSR yang telah diadopsi ke dalam peraturan perundang-undangan, maka dapat ditelusuri lebih lanjut bagaimana prinsip-prinsip yang terdapat dalam ajaran Islam ini diterapkan dalam pengaturan CSR di Indonesia. Berikut ini adalah bagan yang menggambarkan penerapan prinsipprinsip Islam dalam peraturan perundang-undangan:

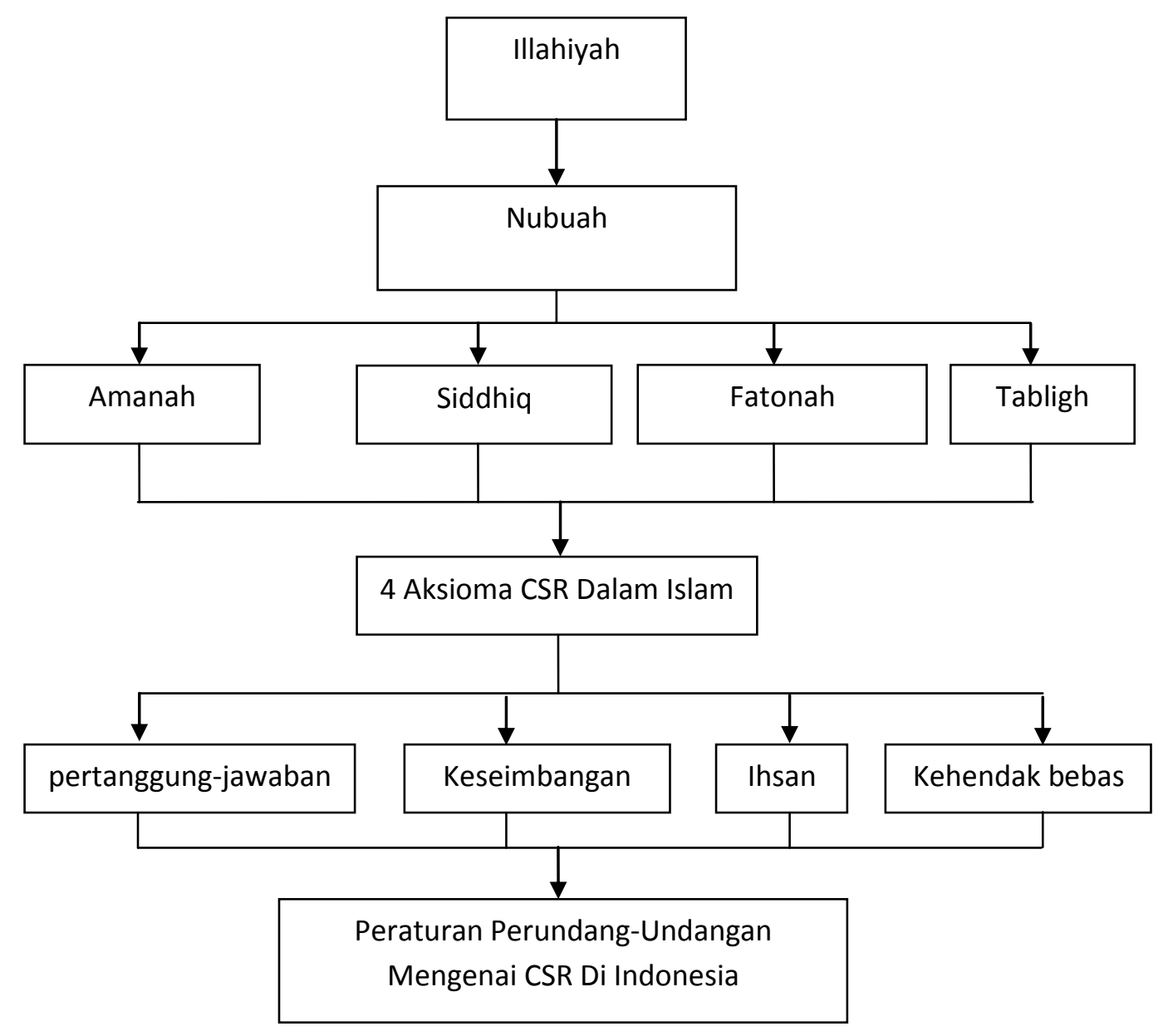


Berdasarkan bagan di atas dapat dilihat bahwa prinsip utama dalam Islam adalah prinsip tauhid atau illahiyah, prinsip ini berarti bahwa segala sesuatu di alam semesta adalah makhluk hidup dan Allah merupakan satu-satunya Pencipta. Pada hakekatnya tauhid harus menjadi landasan untuk setiap Muslim dalam menjalankan segala aktivitas kehidupannya, tidak terkecuali dalam melakukan kegiatan bisnis. Setiap aktivitas bisnis harus dipandang sebagai ibadah, terjadi kesatuan antara kegiatan bisnis dengan moralitas yang bertujuan untuk mendapatkan keridhaan Allah. Dari pemahaman di atas dapat diambil pemaknaan bahwa prilaku bisnis bukan semata-mata perbuatan dalam hubungan kemanusiaan semata tetapi mempunyai sifat Ilahiyah. Adanya sikap kerelaan diantara yang berkepentingan, dan dilakukan dengan keterbukaan merupakan cirri-ciri

dan sifat-sifat keharusan dalam bisnis. Jika ciri-ciri dan sifat-sifat di atas tidak ada, maka bisnis yang dilakukan tidak akan mendapat keuntungan dan manfaat. Prinsip tauhid ini terkait dengan prinsip-prinsip nubuah (sifat Rasulullah) yang terdiri dari shiddiq, fathanah, amanah dan tabligh. Sifat nubuah lebih menngambarkan etika bisnis dalam Islam, karena telah diajarkan Nabi Muhammad dalam kehidupan sehari-hari, termasuk dalam menjalankan kegiatan bisnis.

Shiddiq berarti mempunyai kejujuran dan selalu melandasi ucapan, keyakinan dan amal perbuatan atas dasar nilai-nilai kebenaran yang diajarkan Islam. Dalam bisnis Islam, kunci utama yang harus dikedepankan adalah kejujuran. Kejujuran ditunjukan dengan setiap perkataan yang dibuktikan dengan perilaku, berpijak pada kebenaran dan sesuai fakta yang ada. Konsisten dalam iman dan nilai-nilai kebaikan, meski menghadapi tantangan. Istiqamah dalam kebaikan ditampilkan dalam keteguhan, kesabaran serta keuletan sehingga menghasilkan sesuatu yang optimal. 
Fathanah berarti mengerti, memahami, dan menghayati secara mendalam segala yang menjadi tugas dan kewajibannya. Sifat ini akan menimbulkan kreatifitas dan kemampuan melakukan berbagai macam inovasi yang bermanfaat. Fathanah juga berarti cerdas, yaitu mampu berpikir secara jernih dan rasional serta mengambil keputusan dengan cepat dan tepat. Dalam dunia bisnis sifat fathanah ini digunakan untuk memberi batasan untuk pelaku bisnis dengan cara mengidentifikasi dan menetapkan hal-hal dan atau kegiatan yang diperbolehkan atau tidak. Fathanah juga dapat diartikan sebagai kemampuan kreatif dan konseptual pelaku bisnis yang berfungsi membentuk, mengubah dan mengembangkan semua potensi kehidupan alam semesta menjadi sesuatu yang konkret dan bermanfaat.

Amanah, tanggung jawab dalam melaksanakan setiap tugas dan kewajiban. Amanah ditampilkan dalam keterbukaan, kejujuran, pelayanan yang optimal, dan ihsan (kebajikan) dalam segala hal. Pelaku usaha harus memiliki amanah dengan menampilkan sikap keterbukaan, kejujuran, pelayanan yang Dengan sifat amanah, pelaku usaha memiliki tanggung jawab untuk mengamalkan kewajiban-kewajibannya. Amanah berarti dapat dipercaya, yaitu menjaga kepercayaan yang diberikan oleh Allah dan orang lain. Dalam berbisnis, pemberian kepercayaan ini diwujudkan dalam berbagai bentuk pertanggungjawaban dan akuntabilitas atas kegiatan-kegiatan bisnis.

Tabligh, mengajak sekaligus memberikan contoh kepada pihak lain untuk melaksanakan ketentuan-ketentuan ajaran Islam dalam kehidupan sehari-hari. Sifat tabligh dapat disampaikan pelaku usaha dengan bijak, sabar, argumentatif, dan persuasif yang dapat menumbuhkan hubungan kemanusiaan yang kuat. Para pelaku usaha dituntut mempunyai kesadaran mengenai etika dan moral, karena keduanya merupakan kebutuhan yang harus dimiliki.

Tabligh mempunyai arti kebenaran, menurut konteks bisnis kebenaran dimaksudkan sebagai niat, sikap dan perilaku benar dalam upaya untuk meraih 
keuntungan. Berpegang pada prinsip kebenaran ini maka etika bisnis Islam sangat menjaga dan berlaku preventif terhadap kemungkinan adanya kerugian salah satu pihak dalam melakukan transaksi, kerjasama atau perjanjian bisnis. Penyampaian kebenaran dalam dunia bisnis diwujudkan dalam bentuk sosialisasi praktik-praktik bisnis yang baik dan bersih, kesediaan pelaku bisnis untuk bertanggungjawab. Kemudian etika sifat-sifat nubuah ini diturunkan menjadi aksioma etika bisnis Islam, dimana prinsip-prinsip Islam ini kemudian diadopsi ke dalam Peraturan Perundang-undangan yang mengatur tentang CSR di Indonesia.

\section{1}

\section{a. Keseimbangan (equilibrium)}

Seorang Muslim juga harus memenuhi keseimbangan nilai yang sama antara nilai sosial dan individual dalam masyarakat, kebahagiaan individu harus mempunyai nilai yang sama dipandang dari sudut sosial. Prinsip ini telah diterapkan ke dalam aturan CSR di Indonesia yaitu UU PT Pasal 1 ayat 3 dan Pasal 74 ayat 2:

\section{a) Pasal 1 angka (3)}

Tanggung Jawab Sosial dan Lingkungan adalah komitmen Perseroan untuk berperan serta dalam pembangunan ekonomi berkelanjutan guna meningkatkan kualitas kehidupan dan lingkungan yang bermanfaat, baik bagi Perseroan sendiri, komunitas setempat, maupun masyarakat pada umumnya.

\section{b) Pasal 74 Ayat 2}

Tanggung jawab sosial dan lingkungan itu merupakan kewajiban perseroan yang dianggarkan dan diperhitungkan sebagai biaya perseroan yang pelaksanaannya dilakukan dengan memperhatikan kepatutan dan kewajaran. 
UU PT mewajibkan setiap perusahan untuk melaksanakan CSR, baik secara langsung atau tidak secara langsung menggunakan sumber daya alam dalam kegiatan usaha perusahaan. Dengan berlakunya pasal ini maka CSR yang semula adalah kewajiban moral yang bersifat sukarela, berubah menjadi kewajiban hukum yang bersifat mengikat.

Prinsip keseimbangan juga dapat dilihat dalam UU BUMN Pasal 2 Ayat (1) huruf e dan Pasal 88 Ayat 1 yang menyatakan bahwa selain mencari keuntungan, peran BUMN adalah juga memberikan bimbingan bantuan secara aktif kepada pengusaha golongan lemah, koperasi dan masyarakat dengan cara menyisihkan sebagian laba bersihnya untuk keperluan pembinaan usaha kecil/koperasi serta pembinaan masyarakat sekitar Badan Usaha Milik Negara.

Prinsip keadilan dan keseimbangan antara aspek ekonomi dan sosial juga dapat dilihat dalam Pasal 16 UU PM yang berbunyi bahwa setiap penanam modal bertanggung jawab menjaga kelestarian lingkungan hidup dan menjamin keselamatan, kesehatan, kenyamanan, dan kesejahteraan pekerja.

\section{b. Kehendak Bebas (free Will)}

Manusia mempunyai suatu potensi dalam menentukan pilihan-pilihan yang beragam, karena kebebasan manusia tidak dibatasi. Tetapi dalam kehendak bebas yang diberikan Allah kepada manusia haruslah sejalan dengan prinsip dasar diciptakannya manusia yaitu sebagai khalifah di bumi yang harus dapat menyeimbangkan antara kepentingan individu dan sosial. Kebebasan diartikan sebagai kebebasan yang sesuai dengan ketentuan Allah yang terdapat dalam $\mathrm{Al}$ Qur'an dan undang-undang serta dibatasi oleh hak orang lain, salah satunya adalah kewajiban melestarikan lingkungan. Pelestarian lingkungan ini disebutkan dalam firman Allah dalam Surat Al Baqarah Ayat 11: 
Dan apabila dikatakan pada mereka: "janganlah kalian berbuat kerusakandimuka bumi", mereka menjawab: "Sesungguhnya kami orang-orang yangmengadakan perbaikan.” (QS. Al Baqarah: 11).

Tanggung jawab manusia untuk memelihara lingkungan hidup dan larangan merusak lingkungan dinyatakan dengan jelas. Peranan dan pentingnya air dalam lingkungan hidup juga ditekankan. Ayat di atas juga menyatakan peringatan mengenai kerusakan lingkungan hidup yang terjadi karena pengelolaan bumi dengan mengabaikan lingkungan sekitar.

Hak mengenai lingkungan yang sehat diatur di dalam Undang-Undang No. 39 tahun1999 Tentang Hak Asasi Manusia yaitu pada Pasal 9 Ayat (2) dan Ayat (3).

Pasal 9 Ayat (2)

Setiap orang berhak hidup tentram, aman, damai, bahagia, sejahtera lahir dan batin.

Pasal 9 Ayat (3)

Setiap orang berhak atas lingkungan hidup yang baik dan sehat.

Dari aturan-aturan hukum tersebut dapat dilihat dengan jelas bahwa masyarakat memiliki hak akan kehidupan sosial yang baik dan atas lingkungan hidup yang sehat. Hak yang dimiliki masyarakat ini harus dipenuhi oleh perusahaan-perusahaan dan pelaku usaha dalam menjalankan roda perekonomian perusahaannya. Selanjutnya kewajiban untuk melakukan pelestarian lingkungan hidup, UU No. 23 tahun 1997 tentang Pengelolaan Lingkungan hidup kemudian diperbaharui dalam No. 32 Tahun 2009 Tentang Perlindungan dan Pengelolaan Lingkungan Hidup yang diatur Pasal 65 sebagai berikut:

(1) Setiap orang berhak atas lingkungan hidup yang baik dan sehat sebagai bagian dari hak asasi manusia; 
(2) Setiap orang berhak mendapatkan pendidikan lingkungan hidup, aksesinformasi, akses partisipasi, dan akses keadilan dalam memenuhi hak atas lingkungan hidup yang baik dan sehat;

(3) Setiap orang berhak mengajukan usul dan/atau keberatan terhadap rencanausaha dan/atau kegiatan yang diperkirakan dapat menimbulkan dampakterhadap lingkungan hidup;

(4) Setiap orang berhak untuk berperan dalam perlindungan dan pengelolaanlingkungan hidup sesuai dengan peraturan perundangundangan;

(5) Setiap orang berhak melakukan pengaduan akibat dugaan pencemaran dan/atauperusakan lingkungan hidup;

(6) Ketentuan lebih lanjut mengenai tata cara pengaduan sebagaimana dimaksud pada ayat (5) diatur dengan peraturan menteri.

Berdasarkan uraian undang-undang di atas jelas bahwa masyarakat memiliki hak atas lingkungan yang baik dan sehat sebagai bagian dari hak asasi manusia yang merupakan hak yang paling mendasar yang dimiliki oleh setiap orang. Lingkungan hidup yang baik dan sehat sangat berperan dalam kelangsungan hidup masyarakat. Masyarakat juga berhak mendapatkan pendidikan lingkungan hidup, akses informasi, akses partisipasi dan akses keadilan dalam memenuhi hak atas lingkungan hidup yang baik dan sehat.

\section{c. Pertanggungjawaban}

Segala kebebasan dalam melakukan bisnis oleh manusia tidak lepas dari pertanggungjawaban yang harus diberikan atas aktivitas yang dilakukan sesuai ketentuan hukum, norma-norma dan etika yang tertuang dalam Al Qur'an dan hadis. Segala tuntunan ini harus dipatuhi dan dijadikan acuan atau landasan dalam menggunakan potensi sumber daya yang dikuasai, sumber daya yang dimiliki harus digunakan hanya untuk melakukan kegiatan bisnis yang diperbolehkan. Pengelolaan bisnis harus juga dilakukan dengan cara-cara yang benar, adil dan mendatangkan manfaat optimal bagi semua pihak yang terlibat dalam kegiatan bisnis yang dilakukan. Al Qur'an menegaskan dalam Surat An 
Nisa Ayat 85, barangsiapa memberikan hasil yang baik, niscaya ia akan memperoleh bagian pahala. Dan barang siapa menimbulkan akibat yang buruk, niscaya ia akan memikul konsekuensinya. Prinsip ini diterapkan dalam UU PT, menurut UU PT perusahaan harus menjabarkan pelaksanaan kegiatan CSR. Pengungkapan CSR yang dilakukan perusahaan ini memang sudah diatur dalam Pasal 66 ayat (1) dan ayat (2) huruf c, pengungkapan tersebut dengan cara dicantumkan dalam laporan tahunan perusahaan.

Pasal 66 ayat (1)

Direksi menyampaikan laporan tahunan kepada RUPS setelah ditelaah oleh Dewan Komisaris dalam jangka waktu 6 (enam) bulan setelah tahun buku Perseroan berakhir.

Pasal 66 ayat (2)

Laporan tahunan sebagaimana dimaksud pada ayat (1) harus memuat sekurang kurangnya:

Pasal 66 ayat (2) huruf c

Laporan pelaksanaan Tanggung Jawab Sosial dan Lingkungan.

Laporan tahunan yang diatur dalam UU Perseroan Terbatas aturannya memang belum tegas untuk menekan perusahaan dalam melaksanakan kegiatan CSR. Bahkan sanksi atau peringatan yang diberikan pada perusahaan jika laporan tahunannya tidak mencantumkan CSR belum jelas. Hal tersebut menjadi koreksi tersendiri dan dibutuhkan kontrol dari pemerintah serta masyarakat akan keberadaan perusahaan-perusahaan yang ada di Indonesia. Sehingga laporan tahunan sebaiknya untuk diatur lebih tegas lagi dalam hal mencantumkan program-program CSR dari suatu perusahaan.

UU PM juga mencantumkan tanggung jawab yang harus dilakukan oleh penanam modal dalam Pasal 15 dan Pasal 16 antara lain menerapkan prinsip tata kelola perusahaan yang baik, melaksanakan CSR, membuat laporan tentang 
kegiatan penanaman modal dan menyampaikannya kepada Badan Koordinasi Penanaman Modal, menghormati tradisi budaya masyarakat sekitar lokasi kegiatan usaha penanaman modal, mematuhi semua ketentuan peraturan perundang-undangan, menjaga kelestarian lingkungan hidup dan menciptakan keselamatan, kesehatan, kenyamanan serta kesejahteraan pekerja.

Ihsan berarti kebaikan atau kebajikan, bentuk kebajikan dalam bisnis adalah sikap kerelaan yang berkaitan erat dengan sikap jujur. Kerelaan diartikan sebagai kesediaan para pihak dalam transaksi, kerjasama atau perjanjian bisnis yang dilakukan dengan jujur. Kejujuran dilaksanakan dalam setiap proses bisnis yang dilakukan tanpa unsur penipuan, hal ini bertujuan untuk menciptakan dan menjaga keharmonisan hubungan antara pelaku bisnis maupun masyarakat. Ihsan juga dapat dilakukan dengan memberikan kebaikan kepada orang lain, misalnya penjadwalan ulang, menerima pengembalian barang yang telah dibeli, pembayaran hutang sebelum jatuh tempo.

Bentuk kebaikan dalam bisnis dapat diaplikasikan sebagai kebersamaan pelaku bisnis dalam membagi dan memikul beban sesuai dengan kemampuan masing-masing, kebersamaan dalam memikul tanggung jawab sesuai dengan beban tugas, dan kebersamaan dalam menikmati hasil bisnis secara proporsional dengan tetap mempertimbangkan nilai-nilai sosial. 


\section{KESIMPULAN DAN SARAN}

\section{C.1. Kesimpulan}

\section{Konsep CSR Dalam Islam}

\section{1) Etika Bisnis Dalam Islam}

Islam adalah agama yang mengatur seluruh sendi kehidupan manusia dan alam semesta, Islam berusaha menyeimbangkan antara nilai moral dan ekonomi. Perumusan etika ekonomi Islam dalam setiap kegiatan bisnis diperlukan untuk memandu segala kegiatan ekonomi seorang Muslim. Etika bisnis Islami tersebut selanjutnya dijadikan sebagai kerangka praktis untuk mengamalkan setiap ajaran agama Islam dalam melakukan setiap kegiatan ekonomi.

Etika di dalam Islam mengacu pada dua sumber yaitu Al Qur'an dan Sunah atau Hadits Nabi, dua sumber ini merupakan sentral segala sumber yang membimbing segala perilaku dalam menjalankan ibadah, perbuatan atau aktivitas umat Islam. 
Perintah Allah memang tidak berhenti hanya pada tatanan ibadah, tetapi juga terkait erat dengan perbuatan-perbuatan baik terhadap sesama manusia dan lingkungan sebagai bukti nyata dari kesalehan sosial dari umat Islam yang dituntut untuk berlaku baik. Di samping itu ajaran Islam melarang perilaku yang buruk dan merugikan terhadap diri sendiri, sesama manusia dan lingkungan. Kegiatan bisnis menurut Islam adalah serangkaian aktivitas bisnis dalam berbagai bentuknya yang tidak dibatasi jumlah kepemilikan barang atau termasuk profitnya, namun dibatasi mengenai cara memperolehnya dan pendayagunaan harta tersebut karena terikat pada aturan halal dan haram.

Halal dan haram adalah persoalan penting dalam ajaran Islam, pedoman untuk setiap Muslim dalam setiap aktivitasnya. Berikut ini transaksi bisnis yang diperbolehkan yaitu penghasilan yang halal, perlakuan yang adil pada pekerja (asas non diskriminatif), kedermawanan dan toleransi, kepercayaan, kebenaran dan kejujuran, kesepatan dan pemenuhan kewajiban/menepati janji.

Transaksi bisnis yang haram dalam Islam adalah bunga/riba, penetapan harga, penimbunan, najasy, kecurangan dan penipuan, menjual barang telarang, gharar (perdagangan dengan unsur ketidakpastian, resiko dan spekulasi).

\section{2) Konsep CSR Dalam Islam}

Secara operasional bisnis dalam Islam dapat mengacu pada dua asas, asas pertama adalah sifat dan perilaku nabi dan rasul dalam beraktifitas termasuk dalam berbisnis yaitu shiddiq, fathonah, amanah, dan tabligh. Asas kedua adalah asas yang dipakai dalam dunia usaha pada umumnya yaitu transparansi, akuntabilitas, responsibilitas, independensi serta kewajaran dan kesetaraan. Kedua asas operasional tersebut diperlukan untuk mencapai kesinambungan (sustainability) dengan memperhatikan kepentingan para pemangku kepentingan (stakeholders).

Konsep CSR yang telah diuraikan sebelumnya sebenarnya terdapat dalam ajaran Islam, Islam sejak lama telah lama membangun sistem kehidupan 
yang berdasarkan prinsip-prinsip sosial dan keadilan. Prinsip-prinsip dasar dalam etika bisnis Islam pertama kali dirumuskan oleh An-Naqvi dalam bukunya Ethics and Economics: An Islamic Synthesis (1981). Rumusan AbNaqvi ini selanjutnya banyak dikutip oleh para penulis kontemporer tentang ekonomi Islam di dunia empat prinsip (aksioma) etika bisnis Islam ini dapat diterapkan dalam sebagai konsep CSR, yaitu tauhid (unity/kesatuan), keseimbangan atau kesejajaran (equilibrium), kehendak bebas (free will), dan tanggung jawab (responsibility).

Islam mengajarkan tanggung jawab agar mampu mengendalikan diri dari tindakan melampaui batas kewajaran dan kemanusiaan. Tanggung jawab ini mencakup tanggung jawab kepada Allah, kepada sesama dan lingkungannya. Hal ini diperlukan untuk melewati proses tujuan Islam menjadi rahmatan lil aa'lamin dapat tercapai.

\section{Penerapan Nilai-Nilai Islam Dalam Pengaturan Corporate Social Responsibility Di Indonesia}

\section{1) Konsep CSR Secara Global}

CSR selalu mengacu pada kenyataan bahwa tanggung jawab sosial perusahaan merupakan bagian penting dari strategi bisnis yang berkaitan erat dengan keberlangsungan usaha dalam jangka panjang. Tanggung jawab sosial lingkungan terkait dengan unsur sustainability (pembangunan keberlanjutan) yang dilakukan oleh perusahaan dalam meningkatkan kualitas hidup perusahaan, lingkungan maupun sosial komunitas setempat.

\section{2) Pengaturan Corporate Social Responsibility Di Indonesia}




\section{a. Undang-Undang No. 40 Tahun 2007}

Dalam UU PT, CSR diatur pada Pasal 1 ayat (3) dan Pasal 74 ayat (1), (2), (3), dan (4) yang intinya adalah bahwa PT yang menjalankan kegiatan usahanya di bidang dan/atau berkaitan dengan sumber daya alam wajib melaksanakan tanggung jawab sosial dan lingkungan. Hal ini berarti bahwa semua PT wajib melaksanakan CSR yang dianggarkan dan diperhitungkan sebagai biaya perseroan yang pelaksanaannya dilakukan dengan memperhatikan kepatutan dan kewajaran. Menurut UU PT perusahaan harus menjabarkan pelaksanaan kegiatan CSR, pengungkapan CSR yang dilakukan perusahaan ini memang sudah diatur dalam Pasal 66 ayat (1) dan ayat (2) huruf c, pengungkapan tersebut dengan cara dicantumkan dalam laporan tahunan perusahaan.

\section{b. Undang-Undang No. 25 Tahun 2007 Tentang Penanaman Modal}

Pasal dalam Undang-Undang No. 25 Tahun 2007 tentang Penanaman Modal yang mengatur terkait CSR, yaitu Pasal 15 dan Pasal 16. Pasal 15 UU No. 25 Tahun 2007 ini menegaskan bahwa dalam melaksanakan penanaman modal baik terhadap pihak penanaman modal asing maupun lokal berkewajiban memperhatikan prinsip tata kelola perusahaan yang baik (GCG) dan juga harus melaksanakan tanggung jawab sosial perusahaan (CSR), dengan demikian prinsip GCG dan CSR dalam hal penanaman modal bukan lagi perupakan suatu tanggung jawab moral tetapi sudah merupakan kewajiban hukum.

\section{c. Undang-Undang Nomor 19 Tahun 2003}

Undang-Undang No. 19 Tahun 2003 tentang BUMN yang mengatur CSR secara lebih terperinci. Dalam UU BUMN dinyatakan bahwa selain mencari keuntungan, peran BUMN adalah juga memberikan bimbingan bantuan secara aktif kepada pengusaha golongan lemah, koperasi dan masyarakat. 
Undang-undang ini kemudian dijabarkan lebih jauh oleh Peraturan Menteri Negara BUMN No. 5 Tahun 2007 yang mengatur mulai dari besaran dana hingga tata cara pelaksanaan CSR, dimana CSR dilaksanakan dalam bentuk program kemitraan dan bina lingkungan (PKBL).

\section{d. Undang-Undang No. 23 Tahun 1997 Tentang Pengelolaan Lingkungan Hidup}

Perwujudan untuk pemenuhan hak atas lingkunagn hidup yaitu dengan munculnya UU No. 4 tahun 1982 tentang Ketentuan Pokok Pengelolaan Lingkungan Hidup yang telah diubah dengan UU No. 23 tahun 1997 tentang Pengelolaan Lingkungan hidup. Apabila dikaitkan dengan maka hak atas lingkungan memang harus dipenuhi oleh perusahaan. Hal tersebut sesuai dengan Pasal-Pasal yang menyangkut CSR, yaitu Pasal 5 ayat (1) dan Pasal 20 ayat (1). Pasal ini mengatur hak atas lingkungan, maka hak tersebut memberikan kepada yang mempunyai suatu tuntutan yang sah guna meminta kepentingannya akan suatu lingkungan hidup yang sehat dan dihormati.

\section{3) Penerapan Nilai-Nilai Islam Dalam Pengaturan Corporate Social Responsibility Di Indonesia}

Prinsip utama dalam Islam adalah prinsip tauhid atau illahiyah, prinsip ini berarti bahwa segala sesuatu di alam semerta adalah makhluk hidup dan Allah merupakan satu-satunya Pencipta. Pada haekekatnya tauhid harus menjadi landasan untuk setiap Muslim dalam menjalankan segala aktivitas kehidupannya, tidak terkecuali dalam melakukan kegiatan bisnis. Setiap aktivitas bisnis harus dipandang sebagai ibadah, terjadi kesatuan antara

kegiatan bisnis dengan moralitas yang bertujuan untuk mendapatkan keridhaan Allah. 
Prinsip tauhid ini kemudian dijabarkan dengan prinsip-prinsip nubuah (sifat Rasulullah) yang terdiri dari shiddiq, tabligh, amanah dan fathanah yang juga diturunkan ke dalam empat (4) aksioma dalam Islam yaitu keseimbangan, kehendak bebas, pertanggungjawaban dan ihsan yang kemudian diadopsi dalam peraturan perundang-undangan mengenai CSR.

\section{C.2. Saran}

1) Pemerintah sebaiknya segera merubah peraturan mengenai CSR agar lebih jelas dan sinkron antara peraturan satu dengan yang lain dan membuat standar kegiatan CSR agar dapat mencapai pembangunan berkelanjutan (sustainable development), tepat sasaran dan sesuai dengan ajaran Islam.

2) Para pihak baik itu Pemerintah, perusahaan dan masyarakat sebaiknya mempelajari CSR secara utuh dengan disandingkan pada prinsip-prinsip Islam agar dapat menjawab tantangan pencapaian keseimbangan triple bottom line. 


\section{DAFTAR PUSTAKA}

\section{Buku}

Al-Khallaf, Abdul Wahab, 1981, Khulasah Tarikh Al-Tasyri (Ikhtisar Sejarah Pembentukan Hukum Islam) Terj. Ali Imran, Surabaya, PT. Bina IImu

Alijoyo, Antonius dan Subarto Zaini, 2004, Komisaris Independen, Penggerak Praktek GCG di Perusahaan, Jakarta, PT. Indeks

Al Shiddieqiyy, Hasbi, 1974, Pengantar Fiqh Mu'amalah, Jakarta, Bulan Bintang

Al-'Utsaimin, Muhammad Shalih, 2004, Pengantar Ilmu Tafsir Terj. Ummu Ismail, Jakarta, Darus Sunah

An-Nabhani, Taqiyuddin, 1996, Membangun Sistem Ekonomi Alternatif Perspektif Islam, Jakarta, Risalah Gusti

Ash-Shalih, Subhi, 1999, Membahas IImu-IImu Al Qur'an, Jakarta, Pustaka al-Firdaus

Asshiddiqie, Jimly, 2003, Beberapa Pendekatan Ekonomi Dalam Hukum, Jakarta, Pusat Studi Hukum Tata Negara FH UI

Ambadar, Jackie, 2008, CSR Dalam Pratik Di Indonesia, Jakarta, PT. Elex Media Komputindo

Anshori, Abdul Ghofur, 2006, Filsafat Hukum, Sejarah, Aliran Dan Pemaknaan, Yogyakarta, Gadjah Mada University Press

Basyarahil, A. Aziz Salim, 1992, 22 Masalah Agama, Jakarta, Gema Insani Press

Badzrulzaman Mariam Darus, 2001, Kompilasi Hukum Perikatan, Bandung, Citra Aditya Bakti

Beekun, Rafik Issa, 2004, Etika Bisnis Islami Terj. Muhammad, Yogyakarta, Pustaka Pelajar Offset

Djaafar, T. Zahara, 2001, Pendidikan Non Formal Dan Peningkatan Sumber Daya Manusia Dalam Pembangunan, Padang, FIP UNP 
Ernawan, Erni R., 2007, Business Ethics: Etika Bisnis, Bandung, CV. Alfabeta

Karim, Adiwarman, 2003, Bank Islam: Analisis Fiqh Dan Keuangan, Jakarta, IIIT Indonesia

Hafidhuddin, Didin, 2003, Tafsir al-Hijri, Jakarta, Yayasan Kalimah Thayyibah

Huda, Nurul dan Mustafa Edwin Nasution, 2007, Investasi pada Pasar Modal Syari'ah, Jakarta, Kencana

Kamali, Muhammad Hashim, 1996, Prinsip dan Teori-teori Hukum Islam Terj. Noorhaidi, Yogyakarta, Pustaka Pelajar

Keraf, A. Sony, 2007, Etika Bisnis, Yogyakarta, Pustaka Filsafat Kanisius

Khon, Abdul Majid, 2009, Ulumul Hadits, Jakarta, Bumi Aksara

Kusumaatmadja, Mochtar, 2002, Konsep-Konsep Hukum Dalam Pembangunan, Bandung, Alumni

Jasiman, 2010, Mengenal Dan Memahami Islam, Solo, PT. Era Adicitra Intermedia,

Lajnah Pentashih Mushaf Al Qur'an, 2009, Syamil Al Qur'an: Al Qur'an dan Terjemahannya, Bandung, PT. Sygma Examedia Arkanleema

Lako, Andreas, 2011, Dekontrusi CSR Dan Reformasi Paradigma Bisnis Dan Akutansi, Jakarta, Erlangga

Mannan, Muhammad Abdul 1993, Teori dan Praktek Ekonomi Islam, Jakarta: PT. Dana Bhakti Wakaf

Marzuki, Peter Mahmud, 2007, Penelitian Hukum, Jakarta, Prenada Media Group Kencana

Mertokusumo, Sudikno, 1996, Penemuan hukum, Yogyakarta, Liberty

Muhaimin, 1994, Dimensi-dimensi Studi Islam, Surabaya, Karya Abditama

Muhammad dan Lukman Fauroni, 2002, Visi Al Qur'an tentang Etika dan Bisnis, Jakarta, Salemba Diniyah 
Munawwir, Ahmad Warson, 1984, Al-Munawwir: Kamus Arab Indonesia, Yogyakarta, PP. Al-Munawwir Krapyak

Muslich, 2004, Etika Bisnis Islami: Landasan Filosofis, Normatif, dan Substansi Implementatif, Yogyakarta, Ekonisia Fakultas Ekonomi UII

Naqvi, Syed Nawab, 1993, Ethict and Economics: An Islamic Syntesis, telah diterjemahkan oleh Husin Anis: Etika dan IImu Ekonomi Suatu Sintesis Islami, Bandung, Mizan

Naqvi, Syed Nawab, 2003, Menggagas IImu Ekonomi Islam terj. M. Saiful Anain dan Muhammad Ufuqul Mubin, Yogyakarta, Pustaka Pelajar Offset

Pratley, Peter, 1997, Etika Bisnis (The essence of Bussiness Ethic), Terj. Gunawan Prasetoi, Yogyakarta, Penerbit Andi Dan Simon \& Schuster (Asia) Pte, Ltd.

Qardhawi, Muhammad Yusuf, 1993, Halal dan Haram dalam Islam Terj. Mu'ammal Hamidy, PT. Bina IImu

Qardhawi, Muhammad Yusuf, 1997, Norma Dan Etika Ekonomi Islam, Jakarta, Gema Insani

Rahardjo, Satjipto, 2000, IImu Hukum, Bandung, PT. Citra Aditya Bakti

Rahman, Asmuni A., 1975, Qaidah-Qaidah Fiqih, Jakarta, Bulan Bintang,

Rahman, Fazlur, 1995, Doktrin Ekonomi Islam, Terj. Nastangin dan Soeroyo, Jilid I, Yogyakarta, Dana Bhakti Wakaf

Robbyantono, E. dan Eman Sukirman, 2005, Analisa Kelayakan Bisnis dalam Are You an Entrepreneur Bekasi, Pustaka Inti

Salim, Syaikh 2006, Al-Manaahisy Syar'iyyah fii Shahiihis Sunah anNabawiyyah atau Ensiklopedi Larangan Menurut Al Qur'an dan As-Sunah, terj. Abu Ihsan Al-Atsari, Jakarta, Pustaka Imam Syafi'i

Saphiro, Ian, 2006, Asas dan Moral dalam Politik, Jakarta, Yayasan Obor Indonesia bekerjasama dengan Kedutaan Besar Amerika Serikat Jakarta dan Freedom Institute 
Sedarmayanti, 2003, Good Governance(Kepemerintahan Yang Baik) Dalam Rangka Otonomi Daerah, Bandung, Mandar Maju,

Siahaan, N.H.T, 2004, Hukum Lingkungan dan Ekologi Pembangunan, Jakarta, Penerbit Erlangga

Simanjuntak, Cornelius dan Natalie Mulia, 2009, Organ Perseroan Terbatas, Jakarta, Sinar Grafika

Soekanto, Soerjono, 1986, Pengantar Penelitian Hukum, Jakarta, UI Press

Solihin, Ismail, 2009, Corporate Social Responsibility From Charity To Sustainability, Jakarta, Salemba Empat

Suharto, Edi, 2007, Pekerjaan Sosial Di Dunia Industri, Memperkuat Tanggungjawab Sosial Perusahaan (CSR), Bandung, PT. Refika Aditama

Sunggono, Bambang, 1994, Hukum dan Kebijakan Publik, Jakarta, Sinar Grafika

Syafei, Rachmat 2000, Fiqih Muamalah, Bandung, Pustaka Setia,

Tim Penyusun Ensiklopedi Islam, 2005, Ensiklopedi Islam Jilid 3, Jakarta, PT. Ichtiar Baru van Hoeve

Tim Studi Islam IAIN Sunan Ampel, 2010, Pengantar Studi Islam, Surabaya: Sunan Ampel Pers

Tunggal, Amin Widjaja, 2008, Corporate Social Responsibility, Jakarta, Harvarindo

Umary, Barmawie, 1988, Pendidikan Islam, Yogyakarta, Sunan Kalijaga

Velazquez, Manuel G, 2005, Etika Bisnis: Konsep dan Kasus Terj. Ana Purwaningsih, Kurnianto, dan Totok Budi Santoso, Yogyakarta, Penerbit Andi, hlm. 80

Wibisono, Yusuf, 2007, Membedah Konsep Dan Aplikasi CSR, Gresik, Fanscho Publishing

Widjaja, Gunawan Dan Yerimia Ardi Pratama, 2008, Resiko Hukum Dan Bisnis Perusahaan Tanpa CSR, Jakarta, Forum Sahabat

Yusanto, Muhammad Ismail dan Muhammad Karebet Widjajakusuma, 2002, Menggagas Bisnis Islami, Jakarta, Gema Insani Press 
Zahrah, Muhammad Abu, 2005 Ushul Fiqh Terj. Saefullah Ma'sum, Jakarta, Pustaka Firdaus

Zuhudi, Masjfuk, 1970, Masail Fiqhiyah. Jakarta, PT. Gunung Agung

\section{Peraturan Perundang-undangan}

Republik Indonesia, 1945, Undang-Undang Dasar Negara Republik Indonesia Tahun 1945, www.hukumonline.com

Republik Indonesia, 2004, Undang-Undang Nomor 10 Tahun 2004 Tentang Pembentukan Peraturan Perundang-Undangan, www.hukumonline.com

Republik Indonesia, 2009, Undang-Undang Nomor 32 Tahun 2009 Tentang Perlindungan Dan Pengelolaan Lingkungan Hidup, www.hukumonline.com

Republik Indonesia, 2007, Undang-Undang Nomor 40 Tahun 2007 Tentang Perseroan Terbatas, www.hukumonline.com

Republik Indonesia, 2003, Undang-Undang Nomor 13 Tahun 2003 Tentang Ketenagakerjaan, www.hukumonline.com

Republik Indonesia, 2003, Undang-Undang Nomor 19 Tahun 2003 Tentang Badan Usaha Milik Negara, www.hukumonline.com

Republik Indonesia, 2007, Undang-Undang Nomor 25 Tahun 2007 Tentang Penanaman Modal, www.hukumonline.com

Republik Indonesia, 1999, Undang-Undang Nomor 39 tahun 1999 Tentang Hak Asasi Manusia, www.hukumonline.com

Republik Indonesia, 1997, Undang-Undang Nomor 23 tahun 1997 Tentang Pengelolaan Lingkungan Hidup, www.hukumonline.com

Republik Indonesia, 2008, Undang-Undang Nomor Tahun 2008 Tentang Usaha Mikro, Kecil Dan Menengah, www.hukumonline.com

Republik Indonesia, 2008, Surat Edaran Menteri Negara BUMN Nomor SE07/MBU/2008 Tentang Pelaksanaan Program Kemitraan Dan 
Bina Lingkungan Dan Penerapan Pasal 74 UU PT, www.hukumonline.com

Republik Indonesia, 2007, Peraturan Menteri Negara BUMN Nomor Per05/MBU/2007 Tentang Program Kemitraan Dan Bina Lingkungan, www.hukumonline.com

Republik Indonesia, 2003, Keputusan Menteri BUMN Nomor Kep236/MBU/2003 Tentang Program Kemitraan Dan Bina Lingkungan, www.hukumonline.com

\section{Jurnal, Makalah dan Internet}

Ardana, I Komang, 2008, Bisnis Dan Tanggung Jawab Sosial, www.ejournal.unud.ac.id (diunduh tanggal 11 Oktober 2009 pukul 16.35 WIB)

Arifin, Zainal, 2008, "Upaya Mewujudkan Pemerintahan Yang Bersih, Bebas Dari Kolusi, Korupsi, Dan Nepotisme Dalam Rangka Otonomi Daerah Di Kabupaten Rejang Lebong", Tesis, Fakultas Hukum Universitas Bengkulu

Asshiddiqie, Jimly, 2007, Cita Negara Hukum Indonesia Kontemporer, (diunduh tanggal 23 Desember 2009, pukul 12.09 WIB)

Dusuki, Asyraf Wajdi dan Humayon Dar, 2005, "Stakeholders' Perceptions of Corporate Social Responsibility of Islamic Banks: Evidence from Malaysian Economy", Advance In Islamic Economic And Finance Journal Vol. 1 (Paper to be presented at the Sixth International Conference on Islamic Economics, to be held in Jakarta, Indonesia, on 21-24 November 2005) (diunduh dari http://islamfinland.files.wordpress.com/2009/08/idb-advances-inislamic-economics-and-finance.pdf pada Tanggal 12 November 2011, Pukul 12.01 WIB)

Efendi, Muhammad Rizka Maulana, 2010, Corporate Social Responsibility Dalam Perspektif Islam,, http://lisensiuinjkt.files.wordpress.com/2010/05/corporate-socialresponsibility-4-presentasi-kajian-lisensi.pdf., (diunduh tanggal 2 Juli 2011, Pukul15.00 WIB)

Gill, Umar, 2008, Understanding Islam's link with Corporate Social Responsibility and Sustainability, 
www.cgrforum.com/library/634375688588346250.pdf (diakses pada tanggal 12 Oktober 2011, Pukul 14.02WIB)

Ginting, Jamin, 2008, "Tinjauan Terhadap Corporate Social Responsibility (CSR) Dalam Corporate Governance (GCG)", Jurnal Law Review Vol. VII, Jakarta, Universitas Pelita Harapan

Hasibuan, Chrysanti, 2006 Sekali Lagi, CSR, http://www.swa.co.id (diunduh tanggal 17 Agustus 2011, pukul 17.07 WIB)

Kusumah, Wiraatmadja Suba, 2010, Aspek Hablumminallah dan Hablumminannas (Ebony \& Ivory, Bagian I) http://www.kalangsunda.net/apps/forums/topics/show/2668787-2aspek-hablumminallah-dan-hablumminannas-ebony-ivorybagian-i- (diunduh pada 11 Oktober 2011, pukul 10.12 WIB)

Marlia, Makna Ani dan Rahmat Hidayat, 2008, Pentingnya Implementasi Corporate Social Responsibility Pada Masyarakat Indonesia, http://mamrh.wordpress.com/2008/07/21/53/ (diunduh 3 Juli 2011 Pukul 21.05 WIB)

Mohammed Jawed Akhtar, 2007, "CSR In Islam", Disertation, AUT University of New Zealand (diunduh dari http://www.kantakji.com/fiqh/Files/Companies/z136.pdf, pada tanggal 11 November 2011, pukul 10.00 WIB)

Prakarsa, Wahjudi, 2000, "Corporate Governance Suatu Keniscayaan," Jurnal Reformasi Ekonomi, Vol. 1 No. 2 Oktober-Desember 2000

Rusydi, Fahmi, 2008, lima dan Qiyas Adalah Juga Sumber Hukum Islam, http://orgawam.wordpress.com/2008/09/28/ijma-dan-qiyasadalah-juga-sumber-hukum-islam/ (diunduh pada 11 Oktober 2011, pukul 10.11 WIB)

Saidi, Zaim, 2009, Komoditas Terlarang dalam Muamalat, http://wakalanusantara.com/detilurl/Komoditas.Terlarang.dalam. Muamalat/196 (diakses pada tanggal 1 November 2011, Pukul $11.00 \mathrm{WIB}$

Sampurna, Muhammad Endro, 2007, Sinergi CSR dengan Perspektif Islam,http://www.csrindonesia.com/data/articles/2008031008333 2-a.pdf (diunduh pada tanggal 12 Oktober 2011, pukul 10.12 WIB)

Suharto, Edi, 2009, Menggagas Standar Audit Program CSR Initiating Audit Standard of CSR Program, 
http://www.policy.hu/suharto/Naskah\%20PDF/CSRAudit.pdf. (diunduh 3 Oktober 2009 Pukul 17.05 WIB)

Suharto, Edi, 2009, Welfare State Dan Pembangunan Kesejahteraan Sosial, www.policy.hu, (diunduh tanggal 23 Desember 2009, pukul 12.04 WIB)

Wahid, Ramli Abdul, 2010, Islam Dan Penegakan Hak Asasi Manusia, http://ramliaw.wordpress.com/2010/09/19/islam-dan-penegakanhak-asasi-manusia/ (diunduh pada tanggal 19 September 2011, pukul 10.19 WIB)

Wahyudi, Ade Ilham, 2010, Pandangan Islam Tentang CSR, http://kseiprogres.blogspot.com/2010/01/pandangan-islamtentang-csr.html (diunduh pada 11 Oktober 2011, pukul 10.12 WIB)

Warta Warga, 2009, Pengertian Koperasi Dan Sistem-Sistem, http://wartawarga.gunadarma.ac.id/2009/11/pengertian-koperasidan-sistem-sistem (diakses tanggal 23 Desember 2009, pukul 12.15) 